NBER WORKING PAPER SERIES

\title{
CURRENT ACCOUNT BALANCES, FINANCIAL DEVELOPMENT AND INSTITUTIONS: ASSAYING THE WORLD "SAVINGS GLUT"
}

\author{
Menzie D. Chinn \\ Hiro Ito \\ Working Paper 11761 \\ http://www.nber.org/papers/w11761 \\ NATIONAL BUREAU OF ECONOMIC RESEARCH \\ 1050 Massachusetts Avenue \\ Cambridge, MA 02138 \\ November 2005
}

We thank Steve Kamin, Jaewoo Lee, Catherine Mann and Eswar Prasad for helpful comments on earlier versions of this paper. Jian Wang assisted ably in the compilation of the data set. Chinn acknowledges the financial support of faculty research funds of the University of Wisconsin. The views expressed herein are those of the author(s) and do not necessarily reflect the views of the National Bureau of Economic Research.

(C2005 by Menzie D. Chinn and Hiro Ito. All rights reserved. Short sections of text, not to exceed two paragraphs, may be quoted without explicit permission provided that full credit, including $(\odot$ notice, is given to the source. 
Current Account Balances, Financial Development and Institutions: Assaying the World "Savings Glut"

Menzie D. Chinn and Hiro Ito

NBER Working Paper No. 11761

November 2005

JEL No. F32, F41

\begin{abstract}
We investigate the medium-term determinants of the current account using a model that controls for factors related to institutional development, with a goal of informing the recent debate over the existence and relevance of the "savings glut." The economic environmental factors that we consider are the degree of financial openness and the extent of legal development. We find that for industrial countries, the government budget balance is an important determinant of the current account balance; the budget balance coefficient is 0.21 in a specification controlling for institutional variables. More interestingly, our empirical findings are not consistent with the argument that the more developed financial markets are, the less saving a country undertakes. We find that this posited relationship is applicable only for countries with highly developed legal systems and open financial markets. For less developed countries and emerging market countries we usually find the reverse correlation; greater financial development leads to higher savings. Furthermore, there is no evidence of "excess domestic saving" in the Asian emerging market countries; rather they seem to have suffered from depressed investment in the wake of the 1997 financial crises. We also find evidence that the more developed equity markets are, the more likely countries are to run current account deficits.

\author{
Menzie Chinn \\ Department of Economics \\ University of Wisconsin \\ 1180 Observatory Drive \\ Madison, WI 53706 \\ and NBER \\ mchinn@lafollette.wisc.edu \\ Hiro Ito \\ Department of Economics \\ Portland State University \\ 1721 SW Broadway \\ Portland, OR 97201 \\ ito@pdx.edu
}




\section{Introduction}

The enormous and rapidly widening U.S. current account deficit has been the topic of intense debate in academic and policy circles. As shown in Figure 1, the 2004 ratio of 5.7 percentage points of GDP is high by historical standards, and as documented by Edwards, high in comparison to other developed economies. Mussa (2004) calculates that a sustained current account deficit of 5\% - about a percentage point less than the level projected for 2005 - will result in a net foreign liabilities position of 100\% of GDP.

A number of explanations have been forwarded for the recent widening of the U.S. current account deficit. Roughly speaking, the arguments can be categorized as either domestic or international in nature. Some argue that the main reason for the increase in U.S. current account imbalances is the decline in U.S. savings, especially public sector savings, since 2002. In this “twin deficit” argument, the current administration’s expansionary fiscal policy bears the greatest blame. Greenspan (2005), Ferguson (2005) and others have, on the other hand, argued that the impact of fiscal policy on the current account balance is small.

The "global savings glut” explanation has been expounded by Bernanke (2005), Clarida (2005a,b), and Hubbard (2005). This argument views excess saving from Asian emerging market countries, driven by rising savings and collapsing investment in the aftermath of the financial crisis (and to a lesser extent Europe), as the cause of the U.S. current account deficit. From this perspective, the U.S. external imbalance is a problem made overseas, and amenable to a solution only in the longer term, as better developed financial systems mitigate this excess savings problem.

Surprisingly, despite the popularity of the savings conjecture in (American) policy circles, there has been surprisingly little empirical work that takes seriously the global savings glut theses. ${ }^{1}$ In this paper, we remedy this deficiency by analyzing the determinants of current account balances for industrial and developing countries, while empirically controlling for differences in institutional environment across countries. The data set we employ covers a large and heterogeneous group of countries (117 countries) over a relatively long time span

\footnotetext{
${ }^{1}$ One exception is Gruber and Kamin (2005). Roughly contemporaneously with us, they have written a paper closely related to this one. They examine different aspects of the "savings glut" and "Bretton Woods II" (Dooley, et al., 2005) hypotheses. General discussion of global savings and investment patterns is contained in IMF (2005), CBO (2005), Higgins (2005) and the Economist (2005).
} 
(1971-2003).

Our empirical approach relies upon the approach of Chinn and Prasad (2003). Their study provided a broad empirical characterization of the medium-term determinants of current account balances for a sample of industrial and developing countries from the perspective of longer-run saving-investment balances. This paper updates and extends their work by incorporating a potentially important factor identified by Bernanke (2005), namely the effect of legal and institutional development. ${ }^{2}$

Whether one takes the twin deficits or global savings glut argument, the effect of legal and institutional development cannot be dismissed a priori, although it clearly matters more in the latter case In addition to macroeconomic attributes such as the stage of development, demographic profile, and the government budget balance, the legal environment and the level of institutional development should be important control variables. After all, the extent of private saving and investment should depend upon how the returns from those activities are protected by these factors.

This paper also devotes special attention to the effect of financial development, motivated by the argument that "financial deepening" is one of the important determinants of saving (e.g., Edwards, 1996). While we implement our analysis using a model that controls for financial deepening, part of the current account imbalances for the United States and other countries including emerging market countries in East Asia cannot be explained. We will investigate whether this discrepancy is explained by the development in equity markets. The focus on equity market development is also motivated by the argument that "the U.S. current account is ..., in part, a reflection of a global excess of saving relative to profitable investment opportunities in the post-bubble world.” (Clarida, 2005a).

The main findings are as follows. The budget balance is an important determinant of the current account balance for industrial countries; the coefficient for the budget balance variable is 0.21 in a model controlling for institutional variables. We also find that institutional development is an important determinant for the current account balance, but mainly for higher income countries, although it is important for both saving and investment determination. More importantly, our empirical findings are not consistent with the argument 
that the more developed financial markets are, the less saving a country undertakes. For most of the less developed countries (LDCs) and emerging market group (EMG) countries, if there is, the reverse is true; more financial development leads to higher savings. Furthermore, there is no evidence of "excess domestic saving” in the Asian emerging market countries, though they seem to have suffered from lower investment during the post-crisis period. For the United States, our analysis suggests that it is a saving drought - not investment boom - that is contributing to the enlargement of current account deficits. We also find that for industrialized countries, the deterioration of the current account that is not predicted by our baseline model is associated with the recent boom in equity markets.

\section{Data and Estimation}

\subsection{Theoretical Issues and Variables of Interest}

\subsubsection{Macro Variables}

We base the choice of macroeconomic variables for this exercise on the discussion in Chinn and Prasad (2003).

Net foreign assets to GDP ratio: From an intertemporal perspective, the stock of net foreign assets (NFA) serves as an important initial condition, given that the current account is the sum of the trade balance and the return on a country's stock of NFA (or payment on its net foreign liabilities position). Alternatively, from a buffer stock savings perspective, higher levels of initial net foreign assets should be associated with subsequent lower current account balances. Government budget surplus to GDP ratio: A variety of models predict a positive relationship between government budget balances and current accounts over the medium term. In the absence of a full Ricardian offset via private saving, an increase in the government budget balance could lead to an increase in national saving. In developing economies, where a greater proportion of agents may be liquidity constrained, this relationship might be expected to be more pronounced.

Relative income: The "stages of development” hypothesis for the balance of payments

\footnotetext{
${ }^{2}$ See also Alfaro et al. (forthcoming) for an examination of capital flows and institutions.
} 
suggests that countries, as they move from a low to an intermediate stage of development, typically import capital and, therefore, run current account deficits. As they reach an advanced stage of development, countries run current account surpluses in order to pay off accumulated external liabilities and also to export capital to less advanced economies. Demographics: The literature on the determinants of national saving has pointed to a number of additional "structural” determinants such as demographics. Masson et al. (1998) show that the dependency ratio is one of the key determinants of private saving. Uncertainty: Terms of trade volatility is another potential determinant of medium-term fluctuations in current accounts. Agents in economies that face more volatile terms of trade might save more for precautionary reasons in order to smooth their consumption streams in the face of volatile income flows.

Trade Openness: Country characteristics that reflect macroeconomic policies could also be relevant for current account determination. The degree of openness to international trade could reflect policy choices, including tariff regimes.

These macro data are drawn primarily from the World Bank’s World Development Indicators and supplemented by the IMF's International Financial Statistics and the World Economic Outlook database. Additional details are contained in the Data Appendix.

\subsubsection{Institutional Factors}

\section{Financial Development/Deepening:}

Another determinant of saving [emphasized by Edwards (1995)] is “financial deepening," usually proxied by the ratio of a monetary aggregate such as M2 to GDP. The traditional interpretation of this variable as a measure of the depth and sophistication of the financial system suggests that financial deepening could induce more saving. However, there is a contrasting view that more developed financial markets lessen the need for precautionary saving, and thereby lower the savings rate. Bernanke (2005) argues that greater financial development will remedy the global savings glut in the long run by inducing a decline in the savings rate in the emerging Asia. Relatedly, Clarida (2005) argues that the sophisticated equity markets in the U.S. absorb excess saving from all over the world, leading to higher current account deficits. Given these arguments, we believe that financial market development 
must be taken seriously in any empirical examination.

To measure financial development, we use private credit to GDP (PCGDP) - in contrast to Chinn and Prasad's (2003) use of M2 to GDP - primarily for data availability reasons. ${ }^{3}$ The PCGDP data are drawn from Beck, Demirgüc-Kunt, and Levine (2001).

\section{Financial Openness:}

How open a country is for cross-border financial transactions should also affect capital flows across countries, and thereby the current account. One critique of the global saving glut view focuses on the question of timing - why do excess saving is flow into U.S. financial markets now, and not earlier? A frequent refrain is that, especially for the East Asian economies, comprehensive financial liberalization policies have been implemented, and thereby allowing excess savings to flow into the U.S, and other countries with developed financial markets. Thus, the openness of financial markets should influence countries' current account balances via the impact on saving and investment decisions.

Our metric of financial openness is the Chinn-Ito (2005) index. This index is the first principle component of the binary variables pertaining to cross-border financial transactions based upon the IMF's categorical enumeration reported in Annual Report on Exchange Arrangements and Exchange Restrictions (AREAER). Higher values of this index indicate greater financial openness. Greater detail about the construction of this index can be found in Chinn and Ito (2005). ${ }^{4}$

\section{Legal variables:}

A society's legal foundations and institutions define the context wherein financial transactions and economic decisions are made. This proposition can have implications along

\footnotetext{
${ }^{3}$ One may think of equity market development and its measures. In fact, the dataset of Beck, et al. also contains data to measure the development in equity markets. They are, namely, stock market capitalization (SMKC), total value of stocks traded (SMTV), and stock market turn over ratio (SMTO). However, it is extremely difficult to rely upon these measures as measures of equity market development, because with these measures, one cannot distinguish between market bubble behavior and real market development. Therefore, we do not include equity market development measures in our estimation. However, we will still examine the effect of equity market development using these measures in a later subsection in the way that the aforementioned distinction is less of an issue. See subsection 4.3.
} 
any number of dimensions. Whether the legal system clearly establishes law and order, minimizes corruption, or whether the administrative branch of the government protects property rights efficiently are all important determinants of the incentives to save and invest. Decisions by foreign residents will also be affected.

We incorporate the effect of legal and institutional development by inclusion of the variable $L E G A L$, calculated as the first principal component of law and order ( $L A O)$, corruption (CORRUPT), and bureaucracy quality $(B Q) .{ }^{5}$ The data series are available for the period of 1984 through 1997, but are included in the regression as the period-average. ${ }^{6}$

Summary statistics of the legal variables are displayed in Table $1 .^{7}$ Variable definitions and data sources, along with the list of countries in the sample and country groupings, are presented in the Data Appendix.

\subsection{The Estimation Approach}

The sample for our analysis covers both industrial and developing countries. The underlying database has annual data for 21 industrial and 97 developing countries covering the period 1971-2003. We examine three variables - the current account balance, and its constituents, national saving, and investment, all expressed as a ratio to GDP.

One potential problem with developing country data is the possibility of significant measurement error in annual data. To mitigate these concerns, and since our interest is primarily in medium-term rather than short-term variations in current accounts, we construct a

\footnotetext{
${ }^{4}$ The data are updated to 2003 and cover more countries (163 countries) than what can be found in Chinn and Ito. The updated data are available at http://www.ssc.wisc.edu/ mchinn/.

${ }^{5}$ All of these indexes are available from the ICRG dataset, and are monthly series. Annual series are calculated as the annual average of the monthly series. Higher values indicate better conditions.

${ }^{6}$ In other words, the data on legal/institutional development are cross-sectional in nature, i.e., they are timeinvariant. This is primarily due to data availability. The relative shortness of the time series of the ICRG variables makes it difficult to include these variables as panel data. As Wei (2000) discusses (in reference to the corruption indices in his paper), these types of institutional variables may exhibit some bias. In order to circumvent this issue, we use period averages. However, the inclusion of these variables as time-invariant factors do not pose a substantial problem for our analysis, since these characteristics represented by the legal/institutional variables are likely to change only very slowly.

${ }^{7}$ In the original series, KAOPEN and $L E G A L$ series range between negative and positive values since they are the first principal components. However, in order to avoid the complexity of interpreting the estimated coefficients, these variables are adjusted such that the minimum value is zero, i.e., they range between zero and some positive values. See Table 1.
} 
panel that contains non-overlapping 5-year averages of the data for each country. ${ }^{8}$ This procedure also has the advantage of abstracting from short-run variations in current accounts and related variables, which are not of central interest.

Because the economic environmental factors may affect the way in which financial development might affect saving and investment we include interaction involving these variables. Interactions between the financial development and legal variables (PCGDP times $L E G A L$ ), interactions between the financial development and financial openness variables (PCGDP times KAOPEN), and interactions between legal development and financial openness ( $L E G A L$ times KAOPEN). The financial and legal interaction effect is motivated by the conjecture that deepening financial markets might lead to higher saving rates, but the effect might be magnified under conditions of better developed legal institutions.

Alternatively, if greater financial deepening leads to a lower saving rate or a lower investment rate, that effect could be mitigated when financial markets are equipped with highly developed legal systems. A similar argument can be applied to the effect of financial openness on current account balances.

\section{Empirical Results}

\subsection{The Basic Specification}

We begin our investigation with a basic specification that excludes institutional variables [comparable to that used by Chinn and Prasad (2003)], thereby providing a point of comparison. ${ }^{9}$ The estimation results are reported in Table 2 . Since these results are sensitive to the inclusion of the African countries, we also report separate sets of results with and without the African countries included, both for the full sample and for the developing country sample. We also report separate results for an emerging market group that differs

\footnotetext{
${ }^{8}$ The 2001-03 period has been compressed into one observation, and so represents only 3 years instead of the standard 5.

${ }^{9}$ We include the financial development variable, PCGDP, in the estimation as Chinn and Wei did, though they used M2 as a ratio to GDP. However, we omit the financial openness variable so as to heighten the distinction between the basic macro variables and the environmental factors. In Chinn and Prasad (2003), IMF's AREAER dummies for current account and capital account restrictions ("k2" and "k3") are used to capture effects of restrictions on external transactions. However, these variables turned out to be statistically weak in many regressions.
} 
somewhat from the developing country sample.

One interesting result shown in Table 2 is the significantly positive relationship between current account and government budget balances found for the industrialized countries group. This result differs from the results obtained in Chinn and Prasad (2003), who examined a shorter sample from 1971 to 1995. A one percentage point increase in the budget balance would lead to a 0.19 percentage point increase in the current account balance for industrialized countries and 0.22 for less developed countries except for African countries. While significant, this is substantially less than the estimate obtained by Chinn and Prasad. We attribute this result partly to the differing sample (the estimate is also lower in the 19711995 sample), but also to the difference in behavior of current account balances in recent years.

We regress national saving and investment on the same set of regressors, and report the estimated budget balance coefficients in each of the regressions. The results show that the saving channel does indeed appear to be important in the sense that national saving and public saving are positively correlated, but only for countries with relatively higher income levels such as industrialized countries and emerging market countries. The budget balance appears to have opposite effects on investment between industrialized countries and less developed countries. This issue will be examined in greater detail in a later section.

\section{Estimated coefficients on the government budget balance (\% of GDP) in the regressions without the institutions variables}

\begin{tabular}{l|cccccc}
$\begin{array}{l}\text { Dependent } \\
\text { variable: }\end{array}$ & $\begin{array}{c}\text { All } \\
\text { countries }\end{array}$ & $\begin{array}{c}\text { All excl. } \\
\text { Africa }\end{array}$ & Industrial & $\begin{array}{r}\text { Developing Developing } \\
\text { excl. Africa }\end{array}$ & $\begin{array}{c}\text { Emerging } \\
\text { Market }\end{array}$ \\
\hline Current account & $\mathbf{0 . 1 4 4}$ & $\mathbf{0 . 1 9 0}$ & $\mathbf{0 . 1 8 9}$ & $\mathbf{0 . 1 5 8}$ & $\mathbf{0 . 2 2 3}$ & $\mathbf{0 . 1 5 5}$ \\
National saving & $\mathbf{0 . 1 8 0}$ & $\mathbf{0 . 1 2 1}$ & $\mathbf{0 . 1 9 5}$ & $\mathbf{0 . 1 4 3}$ & 0.017 & $\mathbf{0 . 1 6 4}$ \\
Investment & -0.030 & $\mathbf{0 . 0 0 4}$ & 0.166 & -0.093 & $-0.094^{13 \%}$ & -0.067
\end{tabular}

Bold figures denotes significant at the $10 \%$ level.

One more noteworthy aspect of Table 2 relates to the financial deepening variable. In all subsamples, it exhibits a negative coefficient, albeit only statistically significant for the industrialized countries. Consequently, one can conclude that more developed financial markets do indeed lead to decreased current account balances, but not for the developing countries, as posited by the adherents of the global savings glut thesis. 


\subsection{Augmented Model with Institutional Variables}

We now augment the specification with variables aimed at capturing institutional factors, namely the legal development variable (LEGAL) and associated interaction terms. Tables 3-1 through 3-3 display results from panel OLS regressions with institutional variables. Several notable results are obtained.

First, inclusion of the institutional variable and interaction terms improves the fit of the model, which are observed with improved adjusted R-squared. ${ }^{10}$ We also re-estimate the same regressions using each of the components of the $L E G A L$ variables, namely, CORRUPT, BQ, and $L A O$, in order to isolate which variable drives the results. The test results (not reported) suggest that the corruption index is the most significant contributor among the three institutions variables, followed by the law and order index and bureaucracy quality in the order of significance.

Table 3-1 also shows the regression results. Here again, the significantly positive relationship between current account and government budget balances is detected in all sample groups like in Table 2 where the regression was run without the legal variable and the interaction terms. The estimated coefficient is slightly higher for the LDC and ex-Africa LDC groups. The point estimate is a statistically significant 0.21 for the industrialized countries group, higher than in the previous estimation (0.19), which implies that the coefficient on the budget balance for the IDC group is robust to inclusion of institutional variables.

The null hypothesis that the effect of budget balances on current account balances is zero is rejected, although in this particular specification the economic magnitude of the effect is not large (Note however that a \pm 2 standard error confidence interval encompasses values as high as 0.38). ${ }^{11}$

In their analysis, Gruber and Kamin (2005) obtain similar results. Using a smaller sample of 71 countries over the 1982-2003 period, they find that the budget balance has a

\footnotetext{
${ }^{10}$ Between the models with and without institutional variables, the sample size changes. However, even when it is compared on the exactly same samples, the adjusted R-sq. is found to increase in the models with institutional variables compared to the ones without.
} 
positive effect on the current account, albeit of a smaller magnitude (0.09-0.14). Trade openness also exhibits a similar effect as in our estimates. Perhaps most importantly, they also find that their governance indicators (the Kaufmann et al. measure) induces a reduction in the current account balance. ${ }^{12}$ These findings suggest that several of the key effects we have detected are robust.

When the results across different country groups are compared, the model for the full sample or ex-Africa full sample seems to exhibit more significant coefficients. But we can also observe that the results are driven mainly by the group of industrialized countries. The results for the industrial countries' group indicate that the higher the level of legal development or the more open financial markets are, the lower the current account balances tend to be. ${ }^{13}$ This finding is consistent with an anecdotal view that economies with more developed institutional infrastructure and more open financial markets tend to attract greater foreign capital inflows and thus run current account deficits. However, we should note here that only the group of industrialized countries yields results consistent with such a view. Interestingly, while the same relationship is applicable to the less developed countries group, the effect of legal development is not observed for the ex-Africa LDC group, and furthermore, emerging market countries, to which this argument is often applied to, do not exhibit this characteristic. When the F-test is conducted to test the hypothesis that the institutional variable, the financial openness index, and their interaction terms are jointly zero, the null hypothesis is rejected significantly only for the group of industrialized countries and marginally for the emerging market countries group (with the $p$-value of 15\%). The results also indicate that institutional development is an important determinant of current account balances only for higher income countries.

Although Table 3-1 may not appear to provide promising results for the LDC, ex-

\footnotetext{
11 This finding is very similar to the finding of Erceg et al. (2005) whose simulation results show the coefficient of the budget balance is around 0.20 . The estimated coefficient on the budget balance found in the regressions with individual legal variables, i.e., CORRUPT, $L A O$, and $B Q$, ranges from 0.19 to 0.24 .

${ }^{12}$ In their analysis, they include the change in growth rate, as well as dummy variables for financial crises. On the other hand, they omit measures of capital account openness, financial development as well as terms of trade variability. They also exclude interaction effects involving legal development, thus ruling out nonlinearities of this type.

${ }^{13}$ The significantly positive coefficient on the interaction term between financial openness and legal development may suggest that the effect of each factor is concave depending on the level of the other factor.
} 
Africa LDC or EMG subsamples, it does not necessarily mean that the variables of our interest are unimportant for macroeconomic activity. Inspecting the results from the saving and investment regressions yields additional insights. Essentially, the insignificant results in the current account regressions are a reflection of offsetting effects in the saving and investment regressions, both of which in fact present more significant results (Tables 3-2 and 3-3). Also, for these sets of regressions, the joint hypothesis for the institutional variables and their interaction terms is always rejected, suggesting that institutional development is important for saving and investment determination.

The saving regression with the institutional variables shows that a one percentage point increase in the budget balance leads to a 0.29 percentage point increase in the national saving rate for industrialized countries. While the coefficient is found to be a significantly positive 0.13 for the LDC group, neither ex-Africa LDC or emerging market countries group has a significant coefficient on the budget balance. With these results, we can surmise that for the IDC group, the government budget balance has a non-Ricardian effect on the national saving rate, whereas for the ex-Africa LDC or EMG group, that is not the case. ${ }^{14}$

\footnotetext{
${ }^{14}$ Other studies also find non-Ricardian effects of the government budget balance on national savings such as De Mello, Kongstrud, and Price (2004) for 21 OECD countries, World Bank (2005) for 46 industrialized and emerging market countries, and Gale and Orszag (2004) for the United States. In these studies, the effect of the government budget balance on national savings ranges from 0.50 to 0.80 percent (i.e., the Ricardian offset in private savings ranges from 0.50 to 0.20 percent). Kormendi and Protopapadakis (2005), on the other hand, do not find evidence for the non-Ricardian offset on both the real interest rate and current accounts for the United States.
} 


\section{Estimated coefficients on the government budget balance (\% of GDP) in the regressions with the institutions variables}

\begin{tabular}{l|cccccc}
$\begin{array}{l}\text { Dependent } \\
\text { variable: }\end{array}$ & $\begin{array}{c}\text { All } \\
\text { countries }\end{array}$ & $\begin{array}{c}\text { All excl. } \\
\text { Africa }\end{array}$ & Industrial Developing Developing Emerging \\
excl. Africa & Market \\
\hline Current account & $\mathbf{0 . 1 5 1}$ & $\mathbf{0 . 1 9 1}$ & $\mathbf{0 . 2 1 1}$ & $\mathbf{0 . 1 6 8}$ & $\mathbf{0 . 2 3 0}$ & $\mathbf{0 . 1 5 3}$ \\
National saving & $\mathbf{0 . 1 8 8}$ & $\mathbf{0 . 1 2 5}$ & $\mathbf{0 . 2 8 7}$ & $\mathbf{0 . 1 2 6}$ & -0.036 & 0.123 \\
Investment & -0.008 & 0.012 & $\mathbf{0 . 2 1 5}$ & -0.089 & $\mathbf{- 0 . 1 3 5}$ & -0.103
\end{tabular}

Bold figures denotes significant at the $10 \%$ level.

In the investment regression, the estimated coefficient on the budget balance is significantly positive for the IDC group (0.22), and is significantly negative for the ex-Africa LDC groups (-0.14). There is a contrast between IDC and non-IDC countries in terms of how budget balances affect the level of investment. Given the estimated sign of the coefficient on the budget balance variable, industrialized countries' public financing seems to crowd out investment. ${ }^{15}$ For less developed countries, improving budget balances worsens investment, which means deficit spending usually crowd-in effects on investment among these countries. This is probably because the level of capital formation is already close to the steady state level among industrialized countries.

The effect of financial development on saving and investment is noteworthy as well. The saving regression results show that financial development alone does not seem to have any significant effect on national savings for industrialized countries, but for non-IDC countries, financial development may lead to higher saving rates - PCGDP's coefficient is significantly positive for the LDC and EMG groups. ${ }^{16}$ Since the financial development variable $(P C G D P)$ is interacted with other variables - the legal development measure (LEGAL) and the financial openness variable (KAOPEN) - we need to be careful about interpretation of the effect of financial development. Table 4 shows the total effect of a $10 \%$ point increase in PCGDP conditional on the levels of LEGAL and KAOPEN (the latter as of

\footnotetext{
${ }^{15}$ This is consistent with the non-Ricardian effect on national savings found in the saving regression.

${ }^{16}$ Although the coefficient on PCGDP is not significant for the ex-Africa LDC group, when the insignificant interaction terms between PCGDP and LEGAL and those between KAOPEN and PCGDP are removed from the model, the coefficient on the level term of $P C G D P$ becomes significant with a large magnitude. The coefficient of the interaction term between PCGDP and LEGAL is significantly negative.
} 
the 2001-03 period) - whether their levels are low 10 percentile, mean, or high 10 percentile in each subsample, IDC, LDC, and EMG. Panels A, B, and C show the total effect of financial development on current accounts, national savings, and investment, respectively. Although the regression results for the financial development level or its interactions are not uniformly significant, this exercise illustrates how the impact of financial development can vary with the level of legal development and financial development. ${ }^{17}$ We focus our attention on the total effects on national savings and investment (Panels B and C). ${ }^{18}$

Panel B shows that, for less developed countries and emerging market countries, the effect of higher levels of financial development on national savings is smaller for economies with higher levels of legal development and more open financial markets. Interestingly, Bernanke’s prediction that the more developed financial markets are, the less saving a country undertakes seem to be validated only by industrialized countries with high levels of legal development and relatively closed financial markets, or emerging market countries with high levels of legal development regardless of the openness of financial markets. Especially among emerging market countries with high levels of legal development, the negative effect of financial development is particularly high (0.4 percentage points) if a country has open capital accounts, which appears to bolster Bernanke’s argument that more financial opening and financial development will solve the issue of the savings glut in emerging market countries, especially those in East Asia. Now the next question is, is this finding applicable to emerging market Asian countries?

Panel A of Table 5 categorizes emerging market countries in East Asia depending on the level of legal development and financial openness. The matrix shows that only Hong Kong and Singapore are categorized as countries with highest tenth percentile legal development and highest tenth percentile financial openness, while many Asian EMG countries are categorized in the middle legal development groups. Panel B reports the total effects of a 10 percentage point increase in PCGDP on national savings and investment for

\footnotetext{
${ }^{17}$ The regression results for the emerging market countries group are relatively more significant. Our discussions will be focused on this group of countries.

${ }^{18}$ The total effects on savings and investment do not add up to the total effect on current accounts, because the current account regressions account for the covariance of national savings and investment while simply adding two coefficients does not.
} 
Asian EMG and three industrialized countries, Japan, Germany, and the United Kingdom using specific values for each country’s legal development and financial openness measures. ${ }^{19,20}$ According to Panel B, Hong Kong and Singapore are the only countries for which financial development will cause a negative impact on national savings. Other countries will experience an increase in the ratio of national savings to GDP if financial markets develop further. Interestingly, for all the countries except for Singapore, financial development leads to expansion of investment, presumably because of improved credit conditions and financial intermediation which is supported by Panel $\mathrm{C}$ where the effect of financial development is generally higher among countries with low levels of legal development and more closed financial markets. Furthermore, the effect on investment exceeds that on national savings. Armed with these results, we conclude that financial development reduces the level of current account balances, especially for non-U.S. industrialized countries and Asian emerging market countries, but that effect is achieved, not through a reduction in savings rates, but through increased levels of investment.

Lastly, it is interesting to compare the effect of financial opening between industrialized countries and emerging market countries. While more open financial markets leads to lower saving rates among industrialized countries, for emerging market countries financial opening can induce to higher rates of savings. Examination of the coefficient on financial openness in the current account regression indicates that higher levels of financial openness leads to greater capital inflows for industrialized countries, but not for less developed countries.

In sum, these results present evidence against part of the argument that emerging market countries, especially those in East Asia, will experience lower rates of saving once these countries achieve higher levels of financial development and better developed legal infrastructure. Arguments based upon this thesis have inappropriately extended a characterization applicable for industrialized countries to less developed countries.

\footnotetext{
${ }^{19}$ These countries are mainly composed of top 15 countries in terms of the amount of accumulated foreign reserves (excluding gold).

${ }^{20}$ All of the three IDCs belong to the category of middle-level legal development and most open financial markets in the matrix for industrialized countries (not reported).
} 


\section{Are the Current Account Imbalances of the Last Decade Atypical?}

We next ask whether the pattern of current account imbalances observed over the past decade is atypical. One way to examine the alignment of current account balances is to see the predicted values based on the estimation results. Figure 2 displays the implied current account balances for various countries along with 95\% prediction intervals that are calculated using the estimation results shown in Table 3-1. Figure 2 indicates that the U.S. current account deviating from the predicted path in the 2001-03 period. Given that the 2001-03 observation is just outside the \pm 2 standard error band, this indicates that there is something omitted from our model. Similarly, Gruber and Kamin (2005) also find an unexplainable component in the most recent few years.

\subsection{Out-of-Sample Prediction of Current Account Balances}

Another way to explore this question is to conduct out-of-sample predictions for the 1995-2000 and 2001-03 periods using the estimated coefficients from the regressions implemented over the 1975-95 time periods. ${ }^{21}$ As in the previous section, we implement two models, one with only the Chinn-Prasad macro variables and the other augmented with institutional variables (legal development, financial openness, and the interaction terms). For industrialized countries, we use more recent data that are available from the IMF's World Economic Outlook database.

Figure 3 displays the predicted and actual values of current account balances, expressed as a proportion of GDP. The predicted values are calculated using the specifications with and without institutional variables. In Figure 3-1, we can see that actual U.S. current account deficits are larger in 2001-04 than what could be predicted using the pre-1995 estimation results whether we use the model with or without institutional variables. The magnitude of the under-prediction for the 2001-04 period is about 1.7 percentage points and

\footnotetext{
${ }^{21}$ Since the time fixed effects for the post-1995 time periods are not available, we use the average of the time effects for the 1975-1995 period. This exercise allows us to observe how much the actual current account balances in the post-1995 period differ from what could be predicted using the relationships that obtained up to 1995. Generally, when we examine a subsample, the predicted values will be based on the estimation for that sample group. For example, the predicted values for the group of industrialized countries will be based on the
}

(continued...) 
2.5 percentage points based on the models with and without institutional variables, respectively (see below). From the figure, we can surmise that the deterioration of U.S. current accounts can be partly attributed to higher levels of U.S. budget deficits in the time period given the estimated coefficient on the budget balance in Tables 2 and 3-1. However, given the over-prediction of the current account balances (i.e., under-prediction of the current account deficits) for the country, there seem to be other factors contributing to the deterioration of the external balance.

Prediction errors from the estimations with and without institutional variables (PPT)

\begin{tabular}{l|cccc|c|ccc}
\hline & U.S. & Germany & Japan & $\begin{array}{c}\text { ex-G3 } \\
\text { IDC }\end{array}$ & $\begin{array}{c}\text { ex-Africa } \\
\text { LDC }\end{array}$ & China & Korea & $\begin{array}{c}\text { ex-China } \\
\text { Asian } \\
\text { EMG }\end{array}$ \\
\hline w/out inst. vars. & -1.66 & 1.59 & 0.64 & 1.38 & 1.34 & 5.36 & 2.22 & 6.92 \\
w inst. vars. & -2.49 & 1.32 & 0.78 & 0.51 & 1.13 & 5.61 & 2.07 & 7.19 \\
\hline
\end{tabular}

The other panels in Figure 3-1 exhibit an interesting contrast; Germany, Japan, and industrialized countries ex-G3 experienced better current account balances than what is predicted by the models, with the ex-G3 industrial countries under-prediction the most marked.

We repeated the same exercise for the group of less developed countries with particular focus on Asian emerging market countries. Figure 3-2 shows the out-of-sample predictions for these countries, namely, ex-Africa LDCs, Asian emerging market countries excluding China, China, and Korea, based on the models with and without the institutional variables. These figures make it clear that Asian emerging market countries, not just China, are experiencing an unpredictably large amount of current account surplus. In the 2001-03 period, the actual current account balance of China is higher than what the model predicts by more than 5 percentage point, while the Asian emerging market countries excluding China, on average, experienced better current account balances than model predictions by stunning 7 
percentage points. $^{22}$

\subsection{U.S. Saving (Public) Drought vs. Asian Saving Glut?}

Today's 700 billion dollar question is, where does the U.S. current account imbalance come from? The framework we rely upon allows us to examine the determinants of current account balances from the perspective of saving-investment balances. Now, we implement out-of-sample predictions again, but for national saving and investment in the post-1995 period. Figure 4 shows the out-of-sample predictions for U.S. national saving and investment using the estimation model with the institutional variables (whose results are shown in Tables 3-2 and 3-3). In these figures, we can see that the U.S. is experiencing "saving drought" rather than "investment boom,” which is driving the current account balance down.

What about the question of where the unpredictably large current account surpluses of the emerging Asia come from? Figure 5 helps us figure out the answer to that question. From these figures, we can see that the Asian emerging market countries' level of national saving is not as high as the model predicts in the post-1995 period. This result counters the global saving glut argument. On the other hand, when we examine East Asian investment behavior in the bottom of Figure 5, we observe that the investment rate has been considerably lower than predicted, especially since the 1996-2000 period. The resulting conclusion that East Asia is undergoing a investment drought is consistent with the findings of Higgins (2005).

\subsection{The U.S. Current Account Imbalance and the Equity Market}

Our findings indicate that there is an unexplained component of the U.S. deficit. Is this component attributable to excess savings flowing from East Asia? We believe that a domestic factor is at work. Hence, we investigate whether the remarkable behavior of the U.S. equity market has some explanatory power.

Specifically, we examine the correlation between equity markets and the prediction

\footnotetext{
${ }^{22}$ Gruber and Kamin (2005) associate these current account surpluses with the after-effects of financial crises. In this sense, there results are consistent with the precautionary motive for reserve accumulation identified by Aizenman and Lee (2005).
} 
errors from the previous subsection.

We consider three measures of the behavior of equity markets: stock market capitalization (SMKC), total value of stocks traded (SMTV), and stock market turn over ratio (SMTO), all drawn from Beck, et al.(2001). We view SMKC as a measure of the size of equity markets, SMTO as a measure of the activeness of equity markets, and SMTV as a variable incorporating both aspects. Hence, SMKC and to a lesser extent SMTV will capture bubble effects. Figure 6 shows that many countries, notably the United States and Asian EMG countries, experienced the enlargement of equity markets. ${ }^{23}$ These variables are expressed as a ratio to the world average to capture the investors' focus on relative market performance. ${ }^{24}$

In Figure 7, casual empiricism suggests a correlation between the stock market development measures and the prediction errors for industrialized countries (left column) and Asian emerging market countries (right) using two different stock market development measures, relative SMTV and relative SMTO. ${ }^{25}$ In the figures for the IDC subsample, we observe that U.S stock market booms in the 1996-00 and 2001-03 coincides with model overprediction of the current account balance, i.e., the country experienced larger current account deficits than what the model predicted. For the group of Asian emerging market countries, the association between the prediction errors and stock market measures, no such correlation is obvious.

Table 6 reports the results of regressing the prediction errors on the equity market measures. The regression is performed with the weights based on the ratio of GDP to world total (in current PPP). Regional dummies are included in the regression and since the prediction errors are made using the estimated coefficients from the regressions implemented over the 1975-95 time periods, the time fixed dummies for the 1996-2000 and 2001-03 periods are included. When we measure equity market development using stock market total

\footnotetext{
${ }^{23}$ This is also the reason why we decided not to include equity market development measures in our previous regressions. Inclusion of these measures may also cause multicollinearity since the model also includes the private credit creation variable.

${ }^{24}$ We also calculate five-year averages to make it consistent with prediction errors.

${ }^{25}$ Prediction errors are based on the estimation for the subsamples countries belong to. For example, the prediction errors for Thailand are calculated using the estimates from the regression for the EMG subsample, while those for Ireland are calculated using the IDC subsample’s estimates.
} 
values or stock market capitalization, the association between the prediction errors and stock market development is significantly negative, i.e., the higher the level of equity market development is, the more likely it is for the regression model using the data up to 1995 to over-predict the current account balances (under-predict the deficits) in the post-1995 periods. In other words, countries with higher levels of equity market values (either measured as capitalization or traded value) tend to experience worsened current account balances than is predicted by the model. Figure 8 illustrates the out-of-sample prediction errors and their portions that can be explained by the relative SMTV for the U.S., Germany, Japan, the U.K., ex-G3 IDC, China, Korea, and ex-China Asian EMG in the 1996-2000 and 2001-04 periods. The prediction errors for the U.S. and the U.K. are well-explained by the stock market behavior while it cannot be observed in other countries and groups, suggesting that the effect of stock market performance was especially significant in these countries.

We also regressed the prediction errors from the out-of-sample regressions for national savings and investment on the (relative) stock market development measures (not reported). The estimated coefficient on the stock market measures turned out to be significantly negative only for the saving regression with stock market total values. This result is consistent with the recent experience of the U.S. where the dot-com bubble encouraged consumption through wealth effect and depressed measured saving, thus contributing to the deterioration of the current account. ${ }^{26}$

\section{Concluding remarks}

In this paper we have investigated the medium-term determinants of the current account using a model that controls for institutional factors such as financial openness and legal development, with an aim to inform the recent debate over the source of and solution to the "global saving glut" that has thus far lacked empirical content. Our study addresses that gap. Given our motivation, we focused our study on the behavior of current accounts for the

\footnotetext{
${ }^{26}$ See the discussion in Greenspan (2005b). The results are also consistent with Mann and Plück’s (forthcoming) findings. Using disaggregate U.S. trade data, they under-estimated the trade deficit during the recent period

(continued...)
} 
United States and emerging market countries in East Asia.

We confirmed the results obtained by Chinn and Prasad (2003) that - for the industrialized countries - budget balances play an important role in the determination of current account balances. A one percentage point increase in the budget balance is found to raise the current account balance by 0.21 percentage point. While smaller than the coefficient implied by some macro models, the standard errors on the point estimate are sufficiently large so that one cannot rule out a coefficient as high as 0.40 at conventional significance levels. We also found evidence for such a correlation among non-IDC countries. This finding is robust to inclusion of institutional variables, although incorporating financial factors seems to matter more (in a statistical sense) for industrialized countries than less developed countries. Furthermore, we found evidence that the oft-claimed argument about the effect of financial and legal development as well as financial liberalization is only applicable to this group of countries. This suggests that the policy recommendations made by the global saving glut proponents have only a tenuous empirical basis insofar as they relate to East Asia.

We also found that saving per se is not excessive among the East Asian emerging market countries. Rather, these countries have experienced a shortfall in investment. The United States, on the other hand, seems to be experiencing saving drought, including that in the public sector. Furthermore, current account behavior seems be related with equity market development, especially since the last few years of the 1990s. We conclude that the more a country's equity market boomed, the more likely that country was to experience a deterioration of its current account. This last finding suggests that widening of the U.S. deficit over the last ten years is at least in part attributable to the run-up in stock prices at the turn of the millennium. It remains to be seen whether the real estate boom of the last several years has had an analogous effect on the current account deficit. 


\section{Data Appendix}

The data used in this paper were drawn from a number of different sources. We provide below a listing of the mnemonics for the variables used in the analysis, descriptions of these variables and the source(s) from which the primary data for constructing these variables were taken. A listing of the countries in the final sample, along with the country groupings used in the analysis, is also provided below. For most countries, data were available from 1971 through 2003. Taiwanese data are drawn from the Central Bank of China, ICSEAD, and ADB, Key Indicators of Developing Asian and Pacific Countries.

\begin{tabular}{|c|c|c|}
\hline Mnemonic & Source* & Variable description \\
\hline CAGDP & WDI & Current account to GDP ratio \\
\hline GOVBGDP & WDI, IFS & General government budget balance, ratio to GDP \\
\hline NFAGDP & LM, Sinn & Stock of net foreign assets, ratio to GDP \\
\hline RELY & WDI & $\begin{array}{l}\text { Relative per capita income, adjusted by PPP exchange } \\
\text { rates, Measured relative to the U.S., range ( } 0 \text { to } 1)\end{array}$ \\
\hline RELDEPY & WDI & $\begin{array}{l}\text { Youth dependency ratio (relative to mean across all } \\
\text { countries), Population under } 15 \text { / Population between } 15 \\
\text { and } 65\end{array}$ \\
\hline RELDEPO & WDI & $\begin{array}{l}\text { Old dependency ratio (relative to mean across all } \\
\text { countries), Population over } 65 \text { / Population between } 15 \\
\text { and } 65\end{array}$ \\
\hline YGRAVG & WDI & Average real GDP growth \\
\hline YGRSD & WDI & Standard deviation of GDP growth \\
\hline TOTSD & WDI & Standard deviation of terms of trade \\
\hline OPEN & WDI & $\begin{array}{l}\text { Openness indicator: ratio of exports plus imports of goods } \\
\text { and nonfactor services to GDP }\end{array}$ \\
\hline PCGDP & BDL & Banking development, ratio of private credit to GDP \\
\hline SMTV & BDL & $\begin{array}{l}\text { Equity market development, stock market total value as a } \\
\text { ratio to GDP }\end{array}$ \\
\hline SMTO & BDL & Equity market development, stock market turnover \\
\hline K2 & GM, AREAER & Capital controls on current account transactions \\
\hline K3 & GM, AREAER & Capital controls on capital account transactions \\
\hline NSGDP & WDI & National saving, ratio to GDP \\
\hline LEGAL & & $\begin{array}{l}\text { authors calculation General level of legal development, } \\
\text { first principal component of BQ, LAO, and CORRUPT. }\end{array}$ \\
\hline BQ & ICRG & Quality of Bureaucracy \\
\hline LAO & ICRG & Law and order \\
\hline CORRUPT & ICRG & Corruption index \\
\hline KAOPEN & CI & Capital account openness \\
\hline
\end{tabular}

* These are sources for basic data used to construct the corresponding variables. BDL: Beck, Demirgüc-Kunt, and Levine; CI: Chinn and Ito (2005); GM: Gian Maria Milesi-Ferretti (1998); ICRG: International Country Risk Guide; IFS: IMF’s International Financial Statistics; IMF: Other IMF databases; LM: Lane and Milesi-Ferretti (2001); Sinn: Stefan Sinn (1990); and WDI: World Development Indicators. 


\begin{tabular}{lll} 
& Cn & \multicolumn{1}{c}{ Country name } \\
1 & 612 & Algeria \\
2 & 311 & Antigua and Barbuda \\
3 & 213 & Argentina \\
4 & 193 & Australia \\
5 & 122 & Austria \\
6 & 313 & Bahamas, The \\
7 & 419 & Bahrain \\
8 & 513 & Bangladesh \\
9 & 316 & Barbados \\
10 & 638 & Benin \\
11 & 218 & Bolivia \\
12 & 616 & Botswana \\
13 & 223 & Brazil \\
14 & 748 & Burkina Faso \\
15 & 618 & Burundi \\
16 & 662 & Cote d”Ivoire \\
17 & 622 & Cameroon \\
18 & 156 & Canada \\
19 & 626 & Central African Republic \\
20 & 628 & Chad \\
21 & 228 & Chile \\
22 & 924 & China \\
23 & 233 & Colombia \\
24 & 634 & Congo, Rep. \\
25 & 238 & Costa Rica \\
26 & 423 & Cyprus \\
27 & 128 & Denmark \\
28 & 321 & Dominica \\
29 & 243 & Dominican Rep. \\
30 & 248 & Ecuador \\
31 & 469 & Egypt \\
32 & 253 & El Salvador \\
33 & 819 & Fiji \\
34 & 172 & Finland \\
35 & 132 & France \\
36 & 646 & Gabon \\
37 & 648 & Gambia, The \\
38 & 134 & Germany \\
39 & 652 & Ghana \\
& &
\end{tabular}

\begin{tabular}{lllll}
$\underline{\text { ldc }}$ & $\underline{\text { emg }}$ & 40 & 174 & Greece \\
1 & 0 & 41 & 328 & Grenada \\
1 & 0 & 42 & 258 & Guatemala \\
1 & 1 & 43 & 336 & Guyana \\
0 & 0 & 44 & 263 & Haiti \\
0 & 0 & 45 & 268 & Honduras \\
1 & 0 & 46 & 944 & Hungary \\
1 & 0 & 47 & 176 & Iceland \\
1 & 1 & 48 & 534 & India \\
1 & 0 & 49 & 536 & Indonesia \\
1 & 0 & 50 & 178 & Ireland \\
1 & 0 & 51 & 436 & Israel \\
1 & 1 & 52 & 136 & Italy \\
1 & 1 & 53 & 343 & Jamaica \\
1 & 0 & 54 & 158 & Japan \\
1 & 0 & 55 & 439 & Jordan \\
1 & 1 & 56 & 664 & Kenya \\
1 & 0 & 57 & 542 & Korea \\
0 & 0 & 58 & 443 & Kuwait \\
1 & 0 & 59 & 666 & Lesotho \\
1 & 0 & 60 & 668 & Liberia \\
1 & 1 & 61 & 674 & Madagascar \\
1 & 1 & 62 & 676 & Malawi \\
1 & 1 & 63 & 548 & Malaysia \\
1 & 0 & 64 & 556 & Maldives \\
1 & 0 & 65 & 678 & Mali \\
1 & 0 & 66 & 181 & Malta \\
0 & 0 & 67 & 682 & Mauritania \\
1 & 0 & 68 & 684 & Mauritius \\
1 & 0 & 69 & 273 & Mexico \\
1 & 1 & 70 & 686 & Morocco \\
1 & 1 & 71 & 558 & Nepal \\
1 & 0 & 72 & 138 & Netherlands \\
1 & 0 & 73 & 196 & New Zealand \\
0 & 0 & 74 & 278 & Nicaragua \\
0 & 0 & 75 & 692 & Niger \\
1 & 0 & 76 & 694 & Nigeria \\
1 & 0 & 77 & 142 & Norway \\
0 & 0 & 78 & 449 & Oman \\
1 & 1 & 79 & 564 & Pakistan \\
& & & & \\
\hline
\end{tabular}

\begin{tabular}{|c|c|c|c|}
\hline 80 & 283 & Panama & 1 \\
\hline 81 & 853 & Papua New Guinea & 1 \\
\hline 82 & 288 & Paraguay & 1 \\
\hline 83 & 293 & Peru & 1 \\
\hline 84 & 566 & Philippines & 1 \\
\hline 85 & 182 & Portugal & 0 \\
\hline 86 & 453 & Qatar & 1 \\
\hline 87 & 714 & Rwanda & 1 \\
\hline 88 & 456 & Saudi Arabia & 1 \\
\hline 89 & 722 & Senegal & 1 \\
\hline 90 & 718 & Seychelles & 1 \\
\hline 91 & 724 & Sierra Leone & 1 \\
\hline 92 & 576 & Singapore & 1 \\
\hline 93 & 813 & Solomon Is. & 1 \\
\hline 94 & 199 & South Africa & 1 \\
\hline 95 & 184 & Spain & 0 \\
\hline 96 & 524 & Sri Lanka & 1 \\
\hline 97 & 364 & St. Vincent \& the Grenadines & 1 \\
\hline 98 & 732 & Sudan & 1 \\
\hline 99 & 366 & Suriname & 1 \\
\hline 100 & 734 & Swaziland & 1 \\
\hline 101 & 144 & Sweden & 0 \\
\hline 102 & 146 & Switzerland & 0 \\
\hline 103 & 528 & Taiwan & 1 \\
\hline 104 & 738 & Tanzania & 1 \\
\hline 105 & 578 & Thailand & 1 \\
\hline 106 & 742 & Togo & 1 \\
\hline 107 & 369 & Trinidad and Tobago & 1 \\
\hline 108 & 744 & Tunisia & 1 \\
\hline 109 & 186 & Turkey & 1 \\
\hline 110 & 746 & Uganda & 1 \\
\hline 111 & 466 & UAE & 1 \\
\hline 112 & 112 & United Kingdom & 0 \\
\hline 113 & 111 & United States & 0 \\
\hline 114 & 298 & Uruguay & 1 \\
\hline 115 & 299 & Venezuela & 1 \\
\hline 116 & 754 & Zambia & 1 \\
\hline 117 & 698 & Zimbabwe & 1 \\
\hline
\end{tabular}




\section{References}

Aizenman, Joshua and Lee, Jaewoo, 2005. “International Reserves: Precautionary versus Mercantilist Views, Theory and Evidence,” August.

Alfaro, Laura, Sebnem Kalemli-Ozcan and Vadym Volosovych, forthcoming, "Capital Flows in a Globalized World: The Role of Policies and Institutions," in Sebastian Edwards (ed.), Capital Controls and Capital Flows in Emerging Economies: Policies, Practices and Consequences (U. Chicago Press for NBER).

Beck, T., Demirgüc-Kunt, A., and Levine, R., 2001, “A new database on financial development and structure” in Demirgüc-Kunt, A., and Levine, R. (Eds.) Financial Structure and Economic Growth: A Cross-Country Comparison of Banks, Markets, and Development, Cambridge, MA: MIT Press.

Bernanke, Ben, 2005, “The Global Saving Glut and the U.S. Current Account,” Remarks at the Sandridge Lecture, Virginia Association of Economics, Richmond, VA, March 10.

Chinn, Menzie, 2005, “Getting Serious about the Twin Deficits,” Council Special Reports No. 10 .

Chinn, Menzie and Eswar Prasad, 2003, "Medium-Term Determinants of Current Accounts in Industrial and Developing Countries: An Empirical Exploration,” Journal of International Economics 59(1) (January): 47-76. Also NBER Working Paper \#7581 (March 2000).

Chinn, Menzie and Ito, Hiro, 2005, “What Matters for Financial Development? Capital Controls, Institutions, and Interactions,” NBER Working Paper \#11370, also forthcoming in the Journal of Development Economics.

Clarida, Richard 2005a, “Japan, China, and the U.S. Current account deficit,” CATO Journal, Vol. 25, No. 1 (Winter)

Clarida, Richard, 2005b, "Some Thoughts on 'The Sustainability and Adjustment of Global Current Account Imbalances,'” speech given at the Council on Foreign Relations, March 28.

Congressional Budget Office, 2005, “Box 2-3: Global Savings and Investment,” The Budget and Economic Outlook: An Update (Washington, DC: CBO, August).

De Mello, L., P.M. Kongsrud, and R.W.R. Price, 2004, "Saving Behavior and the Effectiveness of Fiscal Policy,” OECD Economics Department Working Paper No. 397 (Paris: Organization for Economic Cooperation and Development). 
Dooley, Michael, David Folkerts-Landau, and Peter Garber, 2003, “An Essay on the Revived Bretton Woods System.” NBER Working Paper, No. 9971 (September).

Economist, 2005, “A Survey of the World Economy: The Great Thrift Shift,” The Economist, Sept 24, 2005.

Edwards, Sebastian, 2005, "Is the U.S. Current Account Deficit Sustainable? And if not, How Costly Is Adjustment Likely to be?” NBER Working Paper \#11541 (August).

, 1996, "Why Are Latin America’s Saving Rates So Low: An International Comparative Analysis,” Journal of Development Economics, Vol. 51.

Erceg, Christopher, Luca Guerrieri, Christopher Gust, 2005, “Expansionary Fiscal Shocks and the Trade Deficit,” International Finance Discussion Paper No. 825 (Board of Governors of the Federal Reserve System: Washington, DC, January).

Ferguson, Roger W., 2004, “Global Imbalances,” Speech at European Institute Roundtable on Financial and Monetary Affairs, Washington, D.C., April 23.

Gale, William and Orszag, Peter, 2004, "Budget Deficits, National Saving, and Interest Rates," Brookings Papers on Economic Activity: 2, Washington, D.C.: Brookings Institution, p. $101-210$.

Greenspan, Alan, 2005a, “Current Account,” at Advancing Enterprise 2005 Conference, London, England, February 4.

Greenspan, Alan, 2005b, “Mortgage Banking,” at American Bankers Association Annual Convention, Palm Desert, California, September 26.

Gruber, Joseph and Steven B. Kamin, 2005, "Explaining the Global Pattern of Current Account Imbalances,” mimeo (Washington, D.C.: Board of Governors of the Federal Reserve System, September).

Higgins, Matthew, 2005, “The Global Investment Slump and the U.S. Current Account Deficit,” mimeo (NY: Federal Reserve Bank of New York, August).

Hubbard, R. Glenn, 2005, “A Paradox of Interest,” Wall Street Journal, June 23.

International Monetary Fund, 2005, “Chapter 2: Global Imbalances: A Saving and Investment Perspective,” World Economic Outlook (Washington, DC: IMF, September).

Kaufmann, Daniel, Aart Kraay, and Massimo Mastruzzi, 2003, “Governance matters III: Governance indicators for 1996-2002,” mimeo (Washington, DC: World Bank, June). 
Kormendi, Roger C. and Aris Protopapadakis, 2005, "Budget Deficits, Real Yields and Current Account Deficits: The Systematic Evidence on Ricardian Equivalence, mimeo, University of Michigan Business School.

Lane, Philip, Milesi-Ferretti, Gian-Maria, 2001. The external wealth of nations: Measures of foreign assets and liabilities for industrial and developing countries, Journal of International Economics 55, 263-94.

Mann, Catherine and Katherina Plück, forthcoming “The U.S. Trade Deficit: A Disaggregate Perspective,” in R. Clarida (ed.) G-7 Current Account Imbalances: Sustainability and Adjustment (U. Chicago Press for NBER).

Masson, Paul, Tamim Bayoumi and Hossein Samiei, 1998, "International Evidence on the Determinants of Private Saving”, The World Bank Economic Review, Vol. 12, No. 3: p. $483-501$.

Milesi-Ferretti, G.M., 1998, "Why Capital Controls? Theory and Evidence,” In: Eijffinger, S., Huizinga, H. (Eds.), Positive political Economy: Theory and Evidence. Cambridge, MA: Cambridge University Press.

Mussa, Michael, 2004, "Exchange Rate Adjustments Needed to Reduce Global Payments Imbalance,” in Bergstein, C.F. and J. Williamson (Eds.): Dollar Adjustment: How Far? Against What?, Institute for International Economics, Washington, D.C.: November.

Sinn, S., 1990. Net external asset positions of 145 Countries, Kieler Studien 234, Kiel University.

Wei, Shang-Jin, 2000, “Local Corruption and Global Capital Flows,” Brookings Papers on Economic Activity, No.2: p.303-354.

World Bank, 2005, World Economic Outlook, Washington, D.C.: World Bank (September). 
Table 1: Summary Statistics of Legal Variables

\begin{tabular}{l|l||c|c|c|c}
\hline & Groups (\# of countries) & Mean & Std. Dev. & Min & Max \\
\hline \hline & Full (118) & 3.08 & 1.60 & 0.00 & 6.50 \\
General level of & ex-Africa Full (88) & 3.41 & 1.65 & 0.13 & 6.50 \\
Legal development & IDC (21) & 5.75 & 0.76 & 4.07 & 6.50 \\
$($ LEGAL) & LDC (97) & 2.50 & 1.06 & 0.00 & 5.34 \\
& ex-Africa LDC (67) & 2.68 & 1.07 & 0.13 & 5.34 \\
& EMG (42) & 3.05 & 1.05 & 0.57 & 5.34 \\
\hline \multirow{5}{*}{ Bureaucracy Quality } & Full (118) & 2.13 & 1.09 & 0.00 & 4.00 \\
(BQ) & ex-Africa Full (88) & 2.36 & 1.08 & 0.00 & 4.00 \\
& IDC (21) & 3.76 & 0.44 & 2.65 & 4.00 \\
& LDC (97) & 1.78 & 0.84 & 0.00 & 3.66 \\
Law and Order & ex-Africa LDC (67) & 1.92 & 0.81 & 0.00 & 3.66 \\
(LAO) & EMG (42) & 2.33 & 0.63 & 0.87 & 3.66 \\
\hline & Full (118) & 3.63 & 1.28 & 1.00 & 6.00 \\
& ex-Africa Full (88) & 3.91 & 1.29 & 1.33 & 6.00 \\
& IDC (21) & 5.59 & 0.58 & 3.85 & 6.00 \\
& LDC (97) & 3.21 & 0.96 & 1.00 & 5.43 \\
& ex-Africa LDC (67) & 3.39 & 0.96 & 1.33 & 5.43 \\
& EMG (42) & 3.45 & 1.02 & 1.33 & 5.43 \\
\hline Corruption index & Full (118) & 3.19 & 1.19 & 1.03 & 6.00 \\
& ex-Africa Full (88) & 3.37 & 1.26 & 1.11 & 6.00 \\
& IDC (21) & 5.09 & 0.73 & 3.52 & 6.00 \\
& LDC (97) & 2.78 & 0.81 & 1.03 & 4.75 \\
& ex-Africa LDC (67) & 2.83 & 0.83 & 1.11 & 4.75 \\
& EMG (42) & 3.08 & 0.86 & 1.11 & 4.57 \\
\hline
\end{tabular}

NOTES: Data are extracted from the ICRG dataset. $L E G A L$ is the first principal component of $B Q, L A O$, and CORRUPT. The first eigenvector for $L E G A L$ was found to be (BQ, $L A O$, CORRUPT)' $=(0.579,0.574,0.578)^{\prime}$, indicating that the variability of KAOPEN is not driven by any particular component variable. All of the original variables are extracted from the ICRG dataset, and are monthly series. Annual series are calculated as the annual average of the monthly series. 
Table 2: Current account regression without institutions variable

\begin{tabular}{|c|c|c|c|c|c|c|}
\hline \multicolumn{7}{|c|}{ Dependent variable: 5-yr average of current account (\% of GDP): 1975 - 2003} \\
\hline & \begin{tabular}{|c|}
$(1)$ \\
Full \\
\end{tabular} & \begin{tabular}{|c|}
$(2)$ \\
w/o Africa \\
\end{tabular} & $\begin{array}{c}\text { (3) } \\
\text { IDC }\end{array}$ & $\begin{array}{c}(4) \\
\text { LDC }\end{array}$ & \begin{tabular}{|c|}
$(5)$ \\
LDC w/o Africa
\end{tabular} & $\begin{array}{c}(6) \\
\text { EMG }\end{array}$ \\
\hline Gov’t budget balance & $\begin{array}{c}0.1442 \\
{[0.0620]^{* *}}\end{array}$ & $\begin{array}{c}0.1896 \\
{[0.0533]^{* * *}}\end{array}$ & $\begin{array}{c}0.1889 \\
{[0.0799]^{* *}}\end{array}$ & $\begin{array}{c}0.1575 \\
{[0.0780]^{* *}}\end{array}$ & $\begin{array}{c}0.2232 \\
{[0.0767]^{* * *}}\end{array}$ & $\begin{array}{c}0.1552 \\
{[0.0728]^{* *}}\end{array}$ \\
\hline Lane’s NFA (initial) & $\begin{array}{c}0.0511 \\
{[0.0097]^{* * *}}\end{array}$ & $\begin{array}{c}0.0686 \\
{[0.0101]^{* * *}}\end{array}$ & $\begin{array}{c}0.0924 \\
{[0.0157]^{* * *}}\end{array}$ & $\begin{array}{c}0.041 \\
{[0.0125]^{* * *}}\end{array}$ & $\begin{array}{c}0.0576 \\
{[0.0149]^{* * *}}\end{array}$ & $\begin{array}{c}0.0329 \\
{[0.0111]^{* * *}}\end{array}$ \\
\hline Relative income & $\begin{array}{c}0.0095 \\
{[0.0344]}\end{array}$ & $\begin{array}{c}-0.044 \\
{[0.0332]}\end{array}$ & $\begin{array}{c}0.0331 \\
{[0.1340]}\end{array}$ & $\begin{array}{c}0.0463 \\
{[0.0746]}\end{array}$ & $\begin{array}{c}-0.0152 \\
{[0.0710]}\end{array}$ & $\begin{array}{c}0.074 \\
{[0.0656]}\end{array}$ \\
\hline Relative income squared & $\begin{array}{c}0.02 \\
{[0.0295]}\end{array}$ & $\begin{array}{c}0.0497 \\
{[0.0287]^{*}}\end{array}$ & $\begin{array}{c}-0.0038 \\
{[0.0868]}\end{array}$ & $\begin{array}{c}-0.0142 \\
{[0.1231]}\end{array}$ & $\begin{array}{c}0.0156 \\
{[0.1120]}\end{array}$ & $\begin{array}{c}-0.0281 \\
{[0.0966]}\end{array}$ \\
\hline Rel. dependency ratio (young) & $\begin{array}{c}-0.0333 \\
{[0.0130]^{* *}}\end{array}$ & $\begin{array}{c}-0.034 \\
{[0.0108]^{* * *}}\end{array}$ & $\begin{array}{c}0.0156 \\
{[0.0259]}\end{array}$ & $\begin{array}{c}-0.0337 \\
{[0.0176]^{*}}\end{array}$ & $\begin{array}{c}-0.0295 \\
{[0.0137]^{* *}}\end{array}$ & $\begin{array}{c}-0.0213 \\
{[0.0157]}\end{array}$ \\
\hline Rel. dependency ratio (old) & $\begin{array}{c}-0.0228 \\
{[0.0109]^{* *}}\end{array}$ & $\begin{array}{c}-0.0125 \\
{[0.0099]}\end{array}$ & $\begin{array}{c}-0.0057 \\
{[0.0171]}\end{array}$ & $\begin{array}{c}-0.0236 \\
{[0.0146]}\end{array}$ & $\begin{array}{l}-0.0087 \\
{[0.0119]}\end{array}$ & $\begin{array}{c}-0.0395 \\
{[0.0123]^{* * *}}\end{array}$ \\
\hline Financial deepening (PCGDP) & $\begin{array}{c}-0.0143 \\
{[0.0081]^{*}}\end{array}$ & $\begin{array}{l}-0.0128 \\
{[0.0086]}\end{array}$ & $\begin{array}{c}-0.0173 \\
{[0.0106]^{*}}\end{array}$ & $\begin{array}{l}-0.0188 \\
{[0.0143]}\end{array}$ & $\begin{array}{l}-0.0086 \\
{[0.0160]}\end{array}$ & $\begin{array}{c}-0.017 \\
{[0.0153]}\end{array}$ \\
\hline TOT volatility & $\begin{array}{c}-0.0289 \\
{[0.0243]}\end{array}$ & $\begin{array}{c}-0.0092 \\
{[0.0210]}\end{array}$ & $\begin{array}{c}0.1146 \\
{[0.0573]^{* *}}\end{array}$ & $\begin{array}{c}-0.0409 \\
{[0.0287]}\end{array}$ & $\begin{array}{c}-0.0262 \\
{[0.0253]}\end{array}$ & $\begin{array}{c}-0.044 \\
{[0.0286]}\end{array}$ \\
\hline Avg. GDP growth & $\begin{array}{c}0.2106 \\
{[0.1725]}\end{array}$ & $\begin{array}{c}0.2329 \\
{[0.1698]}\end{array}$ & $\begin{array}{l}-0.6895 \\
{[0.4730]}\end{array}$ & $\begin{array}{c}0.2916 \\
{[0.2144]}\end{array}$ & $\begin{array}{c}0.3026 \\
{[0.2254]}\end{array}$ & $\begin{array}{c}0.1867 \\
{[0.2621]}\end{array}$ \\
\hline Trade openness & $\begin{array}{c}0.0071 \\
{[0.0109]}\end{array}$ & $\begin{array}{c}0.0125 \\
{[0.0087]}\end{array}$ & $\begin{array}{c}0.0323 \\
{[0.0107]^{* * *}}\end{array}$ & $\begin{array}{l}-0.0006 \\
{[0.0135]}\end{array}$ & $\begin{array}{c}0.0045 \\
{[0.0122]}\end{array}$ & $\begin{array}{c}-0.0082 \\
{[0.0107]}\end{array}$ \\
\hline Oil exporting countries & $\begin{array}{c}0.0329 \\
{[0.0145]^{* *}}\end{array}$ & $\begin{array}{c}0.0252 \\
{[0.0115]^{* *}}\end{array}$ & $\begin{array}{l}- \\
- \\
\end{array}$ & $\begin{array}{c}0.0373 \\
{[0.0150]^{* *}} \\
\end{array}$ & $\begin{array}{c}0.0328 \\
{[0.0128]^{* *}}\end{array}$ & $\begin{array}{c}0.0333 \\
{[0.0161]^{* *}} \\
\end{array}$ \\
\hline Observations & 423 & 329 & 129 & 294 & 200 & 191 \\
\hline Adjusted R-squared & 0.37 & 0.51 & 0.52 & 0.33 & 0.48 & 0.44 \\
\hline
\end{tabular}


Table 3-1: Current account regression with legal development (LEGAL)

\begin{tabular}{|c|c|c|c|c|c|c|}
\hline \multicolumn{7}{|c|}{ Dependent variable: 5-yr average of current account (\% of GDP): 1975 - 2003} \\
\hline & $\begin{array}{l}(1) \\
\text { Full }\end{array}$ & $\begin{array}{c}\text { (2) } \\
\text { Full w/o } \\
\text { Africa }\end{array}$ & $\begin{array}{c}(3) \\
\text { IDC }\end{array}$ & $\begin{array}{c}(4) \\
\text { LDC }\end{array}$ & $\begin{array}{c}(5) \\
\text { LDC w/o } \\
\text { Africa }\end{array}$ & $\begin{array}{c}(6) \\
\text { EMG }\end{array}$ \\
\hline Gov’t budget balance & $\begin{array}{c}0.1508 \\
{[0.0587]^{* *}}\end{array}$ & $\begin{array}{c}0.1906 \\
{[0.0546]^{* * *}}\end{array}$ & $\begin{array}{c}0.2113 \\
{[0.0869]^{* *}}\end{array}$ & $\begin{array}{c}0.1683 \\
{[0.0739]^{* *}}\end{array}$ & $\begin{array}{c}0.2301 \\
{[0.0753]^{* * *}}\end{array}$ & $\begin{array}{c}0.1525 \\
{[0.0749]^{* *}}\end{array}$ \\
\hline Lane's NFA (initial) & $\begin{array}{c}0.053 \\
{[0.0105]^{* * *}}\end{array}$ & $\begin{array}{c}0.0682 \\
{[0.0104]^{* * *}}\end{array}$ & $\begin{array}{c}0.1003 \\
{[0.0176]^{* * *}}\end{array}$ & $\begin{array}{c}0.0433 \\
{[0.0134]^{* * *}}\end{array}$ & $\begin{array}{c}0.0558 \\
{[0.0155]^{* * *}}\end{array}$ & $\begin{array}{c}0.0396 \\
{[0.0115]^{* * *}}\end{array}$ \\
\hline Relative income & $\begin{array}{c}0.047 \\
{[0.0426]}\end{array}$ & $\begin{array}{c}-0.0386 \\
{[0.0384]}\end{array}$ & $\begin{array}{c}0.0098 \\
{[0.1838]}\end{array}$ & $\begin{array}{c}0.0669 \\
{[0.0838]}\end{array}$ & $\begin{array}{c}-0.0131 \\
{[0.0763]}\end{array}$ & $\begin{array}{c}0.0721 \\
{[0.0741]}\end{array}$ \\
\hline Relative income squared & $\begin{array}{c}-0.0025 \\
{[0.0354]}\end{array}$ & $\begin{array}{c}0.0477 \\
{[0.0331]}\end{array}$ & $\begin{array}{c}0.0064 \\
{[0.1177]}\end{array}$ & $\begin{array}{c}-0.0004 \\
{[0.1357]}\end{array}$ & $\begin{array}{c}0.0347 \\
{[0.1249]}\end{array}$ & $\begin{array}{l}-0.0157 \\
{[0.1081]}\end{array}$ \\
\hline Rel. dependency ratio (young) & $\begin{array}{c}-0.039 \\
{[0.0134]^{* * *}}\end{array}$ & $\begin{array}{c}-0.0387 \\
{[0.0110]^{* * *}}\end{array}$ & $\begin{array}{c}-0.003 \\
{[0.0252]}\end{array}$ & $\begin{array}{c}-0.0415 \\
{[0.0204]^{* *}}\end{array}$ & $\begin{array}{c}-0.0383 \\
{[0.0159]^{* *}}\end{array}$ & $\begin{array}{c}-0.0306 \\
{[0.0160]^{*}}\end{array}$ \\
\hline Rel. dependency ratio (old) & $\begin{array}{c}-0.0218 \\
{[0.0108]^{* *}}\end{array}$ & $\begin{array}{c}-0.0122 \\
{[0.0106]}\end{array}$ & $\begin{array}{c}0.0088 \\
{[0.0220]}\end{array}$ & $\begin{array}{c}-0.0252 \\
{[0.0144]^{*}}\end{array}$ & $\begin{array}{c}-0.0071 \\
{[0.0129]}\end{array}$ & $\begin{array}{c}-0.0375 \\
{[0.0121]^{* * *}}\end{array}$ \\
\hline Financial Develop. (PCGDP) & $\begin{array}{c}-0.0231 \\
{[0.0252]}\end{array}$ & $\begin{array}{l}-0.0027 \\
{[0.0259]}\end{array}$ & $\begin{array}{l}-0.0084 \\
{[0.0767]}\end{array}$ & $\begin{array}{c}-0.0366 \\
{[0.0514]}\end{array}$ & $\begin{array}{l}-0.0244 \\
{[0.0532]}\end{array}$ & $\begin{array}{c}0.0519 \\
{[0.0495]}\end{array}$ \\
\hline Legal development (LEGAL) & $\begin{array}{c}-0.0099 \\
{[0.0037]^{* * *}}\end{array}$ & $\begin{array}{c}-0.0065 \\
{[0.0035]^{*}}\end{array}$ & $\begin{array}{c}-0.0208 \\
{[0.0099]^{* *}}\end{array}$ & $\begin{array}{c}-0.01 \\
{[0.0048]^{* *}}\end{array}$ & $\begin{array}{l}-0.0073 \\
{[0.0048]}\end{array}$ & $\begin{array}{c}0.0041 \\
{[0.0066]}\end{array}$ \\
\hline PCGDP x LEGAL & $\begin{array}{c}0.0058 \\
{[0.0051]}\end{array}$ & $\begin{array}{c}0.0018 \\
{[0.0051]}\end{array}$ & $\begin{array}{c}-0.0002 \\
{[0.0136]}\end{array}$ & $\begin{array}{c}0.0024 \\
{[0.0147]}\end{array}$ & $\begin{array}{c}0.0001 \\
{[0.0161]}\end{array}$ & $\begin{array}{l}-0.0196 \\
{[0.0124]}\end{array}$ \\
\hline Financial open. (KAOPEN) & $\begin{array}{c}-0.0049 \\
{[0.0031]}\end{array}$ & $\begin{array}{c}-0.0058 \\
{[0.0030]^{*}}\end{array}$ & $\begin{array}{c}-0.0529 \\
{[0.0217]^{* *}}\end{array}$ & $\begin{array}{c}-0.0089 \\
{[0.0048]^{*}}\end{array}$ & $\begin{array}{c}-0.0082 \\
{[0.0048]^{*}}\end{array}$ & $\begin{array}{c}0.0009 \\
{[0.0056]}\end{array}$ \\
\hline KAOPEN x LEGAL & $\begin{array}{c}0.0015 \\
{[0.0010]}\end{array}$ & $\begin{array}{c}0.0019 \\
{[0.0009]^{* *}}\end{array}$ & $\begin{array}{c}0.0101 \\
{[0.0035]^{* * *}}\end{array}$ & $\begin{array}{c}0.0019 \\
{[0.0023]}\end{array}$ & $\begin{array}{c}0.0015 \\
{[0.0021]}\end{array}$ & $\begin{array}{l}-0.0015 \\
{[0.0025]}\end{array}$ \\
\hline KAOPEN x PCGDP & $\begin{array}{l}-0.0063 \\
{[0.0050]}\end{array}$ & $\begin{array}{l}-0.0065 \\
{[0.0051]}\end{array}$ & $\begin{array}{c}-0.0038 \\
{[0.0069]}\end{array}$ & $\begin{array}{c}0.0095 \\
{[0.0104]}\end{array}$ & $\begin{array}{c}0.0084 \\
{[0.0100]}\end{array}$ & $\begin{array}{c}0 \\
{[0.0079]}\end{array}$ \\
\hline TOT volatility & $\begin{array}{l}-0.0152 \\
{[0.0238]}\end{array}$ & $\begin{array}{c}0.0021 \\
{[0.0239]}\end{array}$ & $\begin{array}{c}0.1082 \\
{[0.0639]^{*}}\end{array}$ & $\begin{array}{l}-0.0272 \\
{[0.0269]}\end{array}$ & $\begin{array}{l}-0.0237 \\
{[0.0266]}\end{array}$ & $\begin{array}{l}-0.0325 \\
{[0.0336]}\end{array}$ \\
\hline Avg. GDP growth & $\begin{array}{c}0.2788 \\
{[0.1970]}\end{array}$ & $\begin{array}{c}0.1671 \\
{[0.2345]}\end{array}$ & $\begin{array}{c}0.0526 \\
{[0.6044]}\end{array}$ & $\begin{array}{c}0.3976 \\
{[0.2338]^{*}}\end{array}$ & $\begin{array}{c}0.3968 \\
{[0.2572]}\end{array}$ & $\begin{array}{c}0.1019 \\
{[0.2763]}\end{array}$ \\
\hline Trade openness & $\begin{array}{c}0.0098 \\
{[0.0108]}\end{array}$ & $\begin{array}{c}0.0198 \\
{[0.0087]^{* *}}\end{array}$ & $\begin{array}{c}0.0199 \\
{[0.0155]}\end{array}$ & $\begin{array}{l}-0.0077 \\
{[0.0161]}\end{array}$ & $\begin{array}{c}0.0054 \\
{[0.0125]}\end{array}$ & $\begin{array}{c}0.0099 \\
{[0.0124]}\end{array}$ \\
\hline Oil exporting countries & $\begin{array}{c}0.0269 \\
{[0.0149]^{*}}\end{array}$ & $\begin{array}{c}0.0224 \\
{[0.0131]^{*}} \\
\end{array}$ & $\begin{array}{l}- \\
- \\
\end{array}$ & $\begin{array}{c}0.0321 \\
{[0.0158]^{* *}}\end{array}$ & $\begin{array}{c}0.0355 \\
{[0.0143]^{* *}}\end{array}$ & $\begin{array}{c}0.0294 \\
{[0.0181]} \\
\end{array}$ \\
\hline Observations & 394 & 324 & 124 & 270 & 200 & 184 \\
\hline Adjusted R-squared & 0.42 & 0.5 & 0.55 & 0.39 & 0.48 & 0.46 \\
\hline
\end{tabular}


Table 3-2: National saving regression with legal development (LEGAL)

\begin{tabular}{|c|c|c|c|c|c|c|}
\hline \multicolumn{7}{|c|}{ Dependent variable: 5-yr average of national saving (\% of GDP): 1975 - 2003} \\
\hline & $\begin{array}{l}(1) \\
\text { Full }\end{array}$ & $\begin{array}{c}\text { (2) } \\
\text { Full w/o } \\
\text { Africa }\end{array}$ & $\begin{array}{c}\text { (3) } \\
\text { IDC }\end{array}$ & $\begin{array}{c}\text { (4) } \\
\text { LDC }\end{array}$ & $\begin{array}{c}(5) \\
\text { LDC w/o } \\
\text { Africa }\end{array}$ & $\begin{array}{c}(6) \\
\text { EMG }\end{array}$ \\
\hline Gov't budget balance & $\begin{array}{c}0.1882 \\
{[0.0555]^{* * *}}\end{array}$ & $\begin{array}{c}0.1249 \\
{[0.0575]^{* *}}\end{array}$ & $\begin{array}{c}0.2869 \\
{[0.0923]^{* * *}}\end{array}$ & $\begin{array}{c}0.1259 \\
{[0.0720]^{*}}\end{array}$ & $\begin{array}{l}-0.0357 \\
{[0.0751]}\end{array}$ & $\begin{array}{c}0.1228 \\
{[0.0869]}\end{array}$ \\
\hline Lane's NFA (initial) & $\begin{array}{c}0.0257 \\
{[0.0087]^{* * *}}\end{array}$ & $\begin{array}{c}0.035 \\
{[0.0111]^{* * *}}\end{array}$ & $\begin{array}{c}0.0384 \\
{[0.0295]}\end{array}$ & $\begin{array}{c}0.0225 \\
{[0.0101]^{* *}}\end{array}$ & $\begin{array}{c}0.0304 \\
{[0.0131]^{* *}}\end{array}$ & $\begin{array}{c}0.01 \\
{[0.0139]}\end{array}$ \\
\hline Relative income & $\begin{array}{c}0.1649 \\
{[0.0595]^{* * *}}\end{array}$ & $\begin{array}{c}0.0015 \\
{[0.0691]}\end{array}$ & $\begin{array}{c}0.1053 \\
{[0.3098]}\end{array}$ & $\begin{array}{c}0.314 \\
{[0.0960]^{* * *}}\end{array}$ & $\begin{array}{c}0.252 \\
{[0.1238]^{* *}}\end{array}$ & $\begin{array}{c}0.3804 \\
{[0.1171]^{* * * *}}\end{array}$ \\
\hline Relative income squared & $\begin{array}{c}-0.0869 \\
{[0.0493]^{*}}\end{array}$ & $\begin{array}{c}0.0237 \\
{[0.0545]}\end{array}$ & $\begin{array}{c}-0.0665 \\
{[0.1902]}\end{array}$ & $\begin{array}{c}-0.3739 \\
{[0.1681]^{* *}}\end{array}$ & $\begin{array}{c}-0.4331 \\
{[0.1927]^{* *}}\end{array}$ & $\begin{array}{c}-0.4237 \\
{[0.1909]^{* *}}\end{array}$ \\
\hline Rel. dependency ratio (young) & $\begin{array}{c}-0.1238 \\
{[0.0182]^{* * *}}\end{array}$ & $\begin{array}{c}-0.1257 \\
{[0.0188]^{* * *}}\end{array}$ & $\begin{array}{c}-0.1137 \\
{[0.0331]^{* * *}}\end{array}$ & $\begin{array}{c}-0.1072 \\
{[0.0229]^{* * *}}\end{array}$ & $\begin{array}{c}-0.0978 \\
{[0.0274]^{* * *}}\end{array}$ & $\begin{array}{c}-0.0778 \\
{[0.0242]^{* * *}}\end{array}$ \\
\hline Rel. dependency ratio (old) & $\begin{array}{c}-0.0593 \\
{[0.0133]^{* * *}}\end{array}$ & $\begin{array}{c}-0.0563 \\
{[0.0141]^{* * *}}\end{array}$ & $\begin{array}{c}-0.0536 \\
{[0.0305]^{*}}\end{array}$ & $\begin{array}{c}-0.0493 \\
{[0.0187]^{* * *}}\end{array}$ & $\begin{array}{l}-0.0345 \\
{[0.0226]}\end{array}$ & $\begin{array}{c}-0.0554 \\
{[0.0189]^{* * *}}\end{array}$ \\
\hline Financial Develop. (PCGDP) & $\begin{array}{c}0.0376 \\
{[0.0349]}\end{array}$ & $\begin{array}{c}0.071 \\
{[0.0355]^{* *}}\end{array}$ & $\begin{array}{c}0.1183 \\
{[0.0905]}\end{array}$ & $\begin{array}{c}0.1232 \\
{[0.0737]^{*}}\end{array}$ & $\begin{array}{c}0.0474 \\
{[0.0721]}\end{array}$ & $\begin{array}{c}0.2144 \\
{[0.0699]^{* * *}}\end{array}$ \\
\hline Legal development (LEGAL) & $\begin{array}{c}-0.0041 \\
{[0.0051]}\end{array}$ & $\begin{array}{l}-0.0001 \\
{[0.0054]}\end{array}$ & $\begin{array}{c}-0.0084 \\
{[0.0110]}\end{array}$ & $\begin{array}{c}-0.0014 \\
{[0.0066]}\end{array}$ & $\begin{array}{c}-0.0063 \\
{[0.0075]}\end{array}$ & $\begin{array}{c}0.0129 \\
{[0.0097]}\end{array}$ \\
\hline PCGDP x LEGAL & $\begin{array}{c}0.0007 \\
{[0.0060]}\end{array}$ & $\begin{array}{c}-0.0032 \\
{[0.0059]}\end{array}$ & $\begin{array}{c}-0.0243 \\
{[0.0164]}\end{array}$ & $\begin{array}{c}-0.0202 \\
{[0.0186]}\end{array}$ & $\begin{array}{c}0.0034 \\
{[0.0181]}\end{array}$ & $\begin{array}{c}-0.0503 \\
{[0.0203]^{* *}}\end{array}$ \\
\hline Financial open. (KAOPEN) & $\begin{array}{c}0.006 \\
{[0.0043]}\end{array}$ & $\begin{array}{c}0.0031 \\
{[0.0045]}\end{array}$ & $\begin{array}{c}-0.0761 \\
{[0.0205]^{* * *}}\end{array}$ & $\begin{array}{c}0.0081 \\
{[0.0061]}\end{array}$ & $\begin{array}{c}0.0073 \\
{[0.0066]}\end{array}$ & $\begin{array}{c}0.0199 \\
{[0.0081]^{* *}}\end{array}$ \\
\hline KAOPEN x LEGAL & $\begin{array}{c}-0.0023 \\
{[0.0013]^{*}}\end{array}$ & $\begin{array}{c}-0.0013 \\
{[0.0013]}\end{array}$ & $\begin{array}{c}0.0104 \\
{[0.0034]^{* * *}}\end{array}$ & $\begin{array}{c}-0.0015 \\
{[0.0029]}\end{array}$ & $\begin{array}{c}-0.0023 \\
{[0.0030]}\end{array}$ & $\begin{array}{l}-0.0031 \\
{[0.0035]}\end{array}$ \\
\hline KAOPEN x PCGDP & $\begin{array}{c}-0.0053 \\
{[0.0069]}\end{array}$ & $\begin{array}{c}-0.0072 \\
{[0.0069]}\end{array}$ & $\begin{array}{c}0.0109 \\
{[0.0103]}\end{array}$ & $\begin{array}{c}-0.0135 \\
{[0.0124]}\end{array}$ & $\begin{array}{c}0.001 \\
{[0.0120]}\end{array}$ & $\begin{array}{c}-0.0077 \\
{[0.0112]}\end{array}$ \\
\hline TOT volatility & $\begin{array}{c}-0.0255 \\
{[0.0286]}\end{array}$ & $\begin{array}{c}-0.008 \\
{[0.0409]}\end{array}$ & $\begin{array}{c}0.3875 \\
{[0.0831]^{* * *}}\end{array}$ & $\begin{array}{c}-0.0504 \\
{[0.0360]}\end{array}$ & $\begin{array}{c}-0.0955 \\
{[0.0454]^{* *}}\end{array}$ & $\begin{array}{c}-0.2041 \\
{[0.0491]^{* * *}}\end{array}$ \\
\hline Avg. GDP growth & $\begin{array}{c}2.0412 \\
{[0.2245]^{* * *}}\end{array}$ & $\begin{array}{c}1.6171 \\
{[0.2864]^{* * *}}\end{array}$ & $\begin{array}{c}0.4746 \\
{[0.7354]}\end{array}$ & $\begin{array}{c}2.1404 \\
{[0.2665]^{* * *}}\end{array}$ & $\begin{array}{c}2.1589 \\
{[0.4256]^{* * *}}\end{array}$ & $\begin{array}{c}2.2386 \\
{[0.3076]^{* * *}}\end{array}$ \\
\hline Trade openness & $\begin{array}{c}0.0303 \\
{[0.0116]^{* * *}}\end{array}$ & $\begin{array}{c}0.0261 \\
{[0.0114]^{* *}}\end{array}$ & $\begin{array}{c}0.0746 \\
{[0.0212]^{* * *}}\end{array}$ & $\begin{array}{c}0.0243 \\
{[0.0159]}\end{array}$ & $\begin{array}{c}-0.0004 \\
{[0.0156]}\end{array}$ & $\begin{array}{c}-0.0257 \\
{[0.0196]}\end{array}$ \\
\hline Oil exporting countries & $\begin{array}{c}0.0898 \\
{[0.0224]^{* * *}}\end{array}$ & $\begin{array}{c}0.0898 \\
{[0.0264]^{* * *}} \\
\end{array}$ & $\begin{array}{l}- \\
- \\
\end{array}$ & $\begin{array}{c}0.0936 \\
{[0.0235]^{* * *}} \\
\end{array}$ & $\begin{array}{c}0.1162 \\
{[0.0287]^{* * *}} \\
\end{array}$ & $\begin{array}{c}0.1004 \\
{[0.0236]^{* * *}}\end{array}$ \\
\hline Observations & 392 & 323 & 124 & 268 & 199 & 183 \\
\hline Adjusted R-squared & 0.58 & 0.53 & 0.48 & 0.6 & 0.59 & 0.65 \\
\hline
\end{tabular}


Table 3-3: Investment regression with legal development (LEGAL)

\begin{tabular}{|c|c|c|c|c|c|c|}
\hline \multicolumn{7}{|c|}{ Dependent variable: 5-yr average of gross capital formation (\% of GDP): 1975 - 2003} \\
\hline & $\begin{array}{c}\text { (1) } \\
\text { Full }\end{array}$ & $\begin{array}{c}(2) \\
\text { Full w/o } \\
\text { Africa }\end{array}$ & $\begin{array}{c}(3) \\
\text { IDC }\end{array}$ & $\begin{array}{c}(4) \\
\text { LDC }\end{array}$ & $\begin{array}{c}(5) \\
\text { LDC w/o } \\
\text { Africa }\end{array}$ & $\begin{array}{c}(6) \\
\text { EMG }\end{array}$ \\
\hline Gov't budget balance & $\begin{array}{l}-0.0075 \\
{[0.0489]}\end{array}$ & $\begin{array}{c}0.0117 \\
{[0.0516]}\end{array}$ & $\begin{array}{c}0.215 \\
{[0.0903]^{* *}}\end{array}$ & $\begin{array}{l}-0.0888 \\
{[0.0650]}\end{array}$ & $\begin{array}{c}-0.1351 \\
{[0.0636]^{* *}}\end{array}$ & $\begin{array}{l}-0.1033 \\
{[0.0856]}\end{array}$ \\
\hline Lane's NFA (initial) & $\begin{array}{c}-0.0329 \\
{[0.0075]^{* * *}}\end{array}$ & $\begin{array}{c}-0.0186 \\
{[0.0100]^{*}}\end{array}$ & $\begin{array}{l}-0.0167 \\
{[0.0142]}\end{array}$ & $\begin{array}{c}-0.0361 \\
{[0.0088]^{* * *}}\end{array}$ & $\begin{array}{c}-0.022 \\
{[0.0125]^{*}}\end{array}$ & $\begin{array}{c}-0.0264 \\
{[0.0138]^{*}}\end{array}$ \\
\hline Relative income & $\begin{array}{c}0.2014 \\
{[0.0431]^{* * *}}\end{array}$ & $\begin{array}{c}0.143 \\
{[0.0503]^{* * *}}\end{array}$ & $\begin{array}{c}-0.0687 \\
{[0.1515]}\end{array}$ & $\begin{array}{c}0.2671 \\
{[0.0735]^{* * *}}\end{array}$ & $\begin{array}{c}0.259 \\
{[0.0891]^{* * *}}\end{array}$ & $\begin{array}{c}0.294 \\
{[0.0955]^{* * *}}\end{array}$ \\
\hline Relative income squared & $\begin{array}{c}-0.1358 \\
{[0.0336]^{* * *}}\end{array}$ & $\begin{array}{c}-0.0966 \\
{[0.0372]^{* * *}}\end{array}$ & $\begin{array}{c}0.0082 \\
{[0.0990]}\end{array}$ & $\begin{array}{c}-0.2563 \\
{[0.1369]^{*}}\end{array}$ & $\begin{array}{c}-0.2806 \\
{[0.1590]^{*}}\end{array}$ & $\begin{array}{c}-0.3359 \\
{[0.1579]^{* *}}\end{array}$ \\
\hline Rel. dependency ratio (young) & $\begin{array}{c}-0.0572 \\
{[0.0175]^{* * *}}\end{array}$ & $\begin{array}{c}-0.074 \\
{[0.0168]^{* * *}}\end{array}$ & $\begin{array}{c}-0.1226 \\
{[0.0241]^{* * *}}\end{array}$ & $\begin{array}{c}-0.0331 \\
{[0.0219]}\end{array}$ & $\begin{array}{c}-0.0503 \\
{[0.0233]^{* *}}\end{array}$ & $\begin{array}{l}-0.0266 \\
{[0.0247]}\end{array}$ \\
\hline Rel. dependency ratio (old) & $\begin{array}{c}-0.0221 \\
{[0.0120]^{*}}\end{array}$ & $\begin{array}{c}-0.0459 \\
{[0.0126]^{* * *}}\end{array}$ & $\begin{array}{c}-0.0729 \\
{[0.0178]^{* * *}}\end{array}$ & $\begin{array}{c}0.0043 \\
{[0.0153]}\end{array}$ & $\begin{array}{l}-0.0199 \\
{[0.0178]}\end{array}$ & $\begin{array}{c}0.0051 \\
{[0.0176]}\end{array}$ \\
\hline Financial Develop. (PCGDP) & $\begin{array}{c}0.0832 \\
{[0.0289]^{* * *}}\end{array}$ & $\begin{array}{c}0.086 \\
{[0.0316]^{* * *}}\end{array}$ & $\begin{array}{c}0.1353 \\
{[0.0763]^{*}}\end{array}$ & $\begin{array}{c}0.1732 \\
{[0.0585]^{* * *}}\end{array}$ & $\begin{array}{c}0.0993 \\
{[0.0580]^{*}}\end{array}$ & $\begin{array}{c}0.1869 \\
{[0.0689]^{* * *}}\end{array}$ \\
\hline Legal development (LEGAL) & $\begin{array}{c}0.0023 \\
{[0.0045]}\end{array}$ & $\begin{array}{c}0.0071 \\
{[0.0048]}\end{array}$ & $\begin{array}{c}0.0175 \\
{[0.0118]}\end{array}$ & $\begin{array}{c}0.003 \\
{[0.0057]}\end{array}$ & $\begin{array}{c}-0.0004 \\
{[0.0064]}\end{array}$ & $\begin{array}{c}0.0119 \\
{[0.0091]}\end{array}$ \\
\hline PCGDP x LEGAL & $\begin{array}{c}-0.0053 \\
{[0.0054]}\end{array}$ & $\begin{array}{l}-0.0061 \\
{[0.0056]}\end{array}$ & $\begin{array}{c}-0.02 \\
{[0.0116]^{*}}\end{array}$ & $\begin{array}{c}-0.0238 \\
{[0.0146]}\end{array}$ & $\begin{array}{c}-0.0072 \\
{[0.0146]}\end{array}$ & $\begin{array}{c}-0.0334 \\
{[0.0185]^{*}}\end{array}$ \\
\hline Financial Open. (KAOPEN) & $\begin{array}{c}0.0104 \\
{[0.0037]^{* * *}}\end{array}$ & $\begin{array}{c}0.0079 \\
{[0.0037]^{* *}}\end{array}$ & $\begin{array}{c}-0.013 \\
{[0.0162]}\end{array}$ & $\begin{array}{c}0.0132 \\
{[0.0055]^{* *}}\end{array}$ & $\begin{array}{c}0.0097 \\
{[0.0056]^{*}}\end{array}$ & $\begin{array}{c}0.0253 \\
{[0.0075]^{* * *}}\end{array}$ \\
\hline KAOPEN x LEGAL & $\begin{array}{c}-0.0032 \\
{[0.0011]^{* * *}}\end{array}$ & $\begin{array}{c}-0.0031 \\
{[0.0010]^{* * *}}\end{array}$ & $\begin{array}{c}-0.0006 \\
{[0.0026]}\end{array}$ & $\begin{array}{c}-0.002 \\
{[0.0024]}\end{array}$ & $\begin{array}{c}-0.002 \\
{[0.0025]}\end{array}$ & $\begin{array}{c}-0.0056 \\
{[0.0031]^{*}}\end{array}$ \\
\hline KAOPEN x PCGDP & $\begin{array}{c}-0.0035 \\
{[0.0055]}\end{array}$ & $\begin{array}{c}-0.0033 \\
{[0.0056]}\end{array}$ & $\begin{array}{c}0.0053 \\
{[0.0069]}\end{array}$ & $\begin{array}{c}-0.0237 \\
{[0.0117]^{* *}}\end{array}$ & $\begin{array}{c}-0.0131 \\
{[0.0115]}\end{array}$ & $\begin{array}{c}-0.0034 \\
{[0.0110]}\end{array}$ \\
\hline TOT volatility & $\begin{array}{c}0.0123 \\
{[0.0220]}\end{array}$ & $\begin{array}{c}0.029 \\
{[0.0276]}\end{array}$ & $\begin{array}{c}0.2054 \\
{[0.0524]^{* * *}}\end{array}$ & $\begin{array}{c}0.0113 \\
{[0.0255]}\end{array}$ & $\begin{array}{c}-0.001 \\
{[0.0311]}\end{array}$ & $\begin{array}{c}-0.1007 \\
{[0.0389]^{* *}}\end{array}$ \\
\hline Avg. GDP growth & $\begin{array}{c}2.0608 \\
{[0.2222]^{* * *}}\end{array}$ & $\begin{array}{c}1.5594 \\
{[0.2528]^{* * *}}\end{array}$ & $\begin{array}{c}0.7276 \\
{[0.5913]}\end{array}$ & $\begin{array}{c}2.2295 \\
{[0.2451]^{* * *}}\end{array}$ & $\begin{array}{c}2.0312 \\
{[0.3100]^{* * *}}\end{array}$ & $\begin{array}{c}2.0779 \\
{[0.3422] * * *}\end{array}$ \\
\hline Trade Openness & $\begin{array}{c}0.0019 \\
{[0.0107]}\end{array}$ & $\begin{array}{c}0.0041 \\
{[0.0096]}\end{array}$ & $\begin{array}{c}0.0203 \\
{[0.0152]}\end{array}$ & $\begin{array}{c}0.0095 \\
{[0.0152]}\end{array}$ & $\begin{array}{c}0.004 \\
{[0.0158]}\end{array}$ & $\begin{array}{c}-0.008 \\
{[0.0181]}\end{array}$ \\
\hline Oil exporting countries & $\begin{array}{c}0.078 \\
{[0.0140]^{* * *}} \\
\end{array}$ & $\begin{array}{c}0.0555 \\
{[0.0180]^{* * *}} \\
\end{array}$ & $\begin{array}{l}- \\
- \\
\end{array}$ & $\begin{array}{c}0.0806 \\
{[0.0138]^{* * *}} \\
\end{array}$ & $\begin{array}{c}0.0724 \\
{[0.0186]^{* * *}} \\
\end{array}$ & $\begin{array}{c}0.0712 \\
{[0.0214]^{* * *}} \\
\end{array}$ \\
\hline Observations & 413 & 338 & 126 & 287 & 212 & 194 \\
\hline Adjusted R-squared & 0.56 & 0.54 & 0.68 & 0.6 & 0.57 & 0.59 \\
\hline
\end{tabular}


Table 4: Total Effects of a $10 \%$ increase in Financial Development (PCGDP) conditional on legal development and financial openness

\section{A. Current Account}

\begin{tabular}{|c|c|c|c|c|}
\hline \multirow{2}{*}{\multicolumn{2}{|c|}{ Industrialized countries }} & \multicolumn{3}{|c|}{ KAOPEN [0, 4.39] } \\
\hline & & \multirow{2}{*}{$\begin{array}{c}\begin{array}{c}\text { Low } \\
10 \text { percentile } \\
(0.64)\end{array} \\
-0.117\end{array}$} & \multirow{2}{*}{$\begin{array}{c}\begin{array}{c}\text { Mean } \\
(2.99)\end{array} \\
-0.207\end{array}$} & \multirow{2}{*}{$\begin{array}{c}\begin{array}{c}\text { High } \\
10 \text { percentile } \\
(4.39)\end{array} \\
-0.260\end{array}$} \\
\hline \multirow{3}{*}{$\begin{array}{l}\text { LEGAL } \\
{[0,6.50]}\end{array}$} & $\begin{array}{c}\text { Low } \\
10 \text { percentile (4.57) }\end{array}$ & & & \\
\hline & $\begin{array}{l}\text { Mean } \\
(5.75) \\
\end{array}$ & -0.120 & -0.209 & -0.262 \\
\hline & $\begin{array}{c}\text { High } \\
10 \text { percentile (6.47) }\end{array}$ & -0.121 & -0.211 & -0.264 \\
\hline
\end{tabular}

\begin{tabular}{|c|c|c|c|c|}
\hline \multirow{2}{*}{\multicolumn{2}{|c|}{ Less developed countries }} & \multicolumn{3}{|c|}{ KAOPEN [0, 4.39] } \\
\hline & & \multirow{2}{*}{$\begin{array}{c}\begin{array}{c}\text { Low } \\
10 \text { percentile } \\
(0.00)\end{array} \\
-0.337\end{array}$} & \multirow{2}{*}{$\begin{array}{l}\text { Mean } \\
(1.51)\end{array}$} & \multirow{2}{*}{$\begin{array}{c}\begin{array}{c}\text { High } \\
10 \text { percentile } \\
(4.39)\end{array} \\
0.080\end{array}$} \\
\hline \multirow{3}{*}{$\begin{array}{l}\text { LEGAL } \\
{[0,6.50]}\end{array}$} & $\begin{array}{c}\text { Low } \\
10 \text { percentile (1.19) }\end{array}$ & & & \\
\hline & $\begin{array}{l}\text { Mean } \\
(2.50) \\
\end{array}$ & -0.306 & -0.162 & 0.111 \\
\hline & $\begin{array}{c}\text { High } \\
10 \text { percentile (3.81) }\end{array}$ & -0.275 & -0.131 & 0.143 \\
\hline
\end{tabular}

\begin{tabular}{|c|c|c|c|c|}
\hline \multirow{2}{*}{\multicolumn{2}{|c|}{ Emerging market countries }} & \multicolumn{3}{|c|}{ KAOPEN [0, 4.39] } \\
\hline & & \multirow{2}{*}{$\begin{array}{c}\begin{array}{c}\text { Low } \\
10 \text { percentile } \\
(0.00)\end{array} \\
0.160\end{array}$} & \multirow{2}{*}{$\begin{array}{l}\text { Mean } \\
(1.42)\end{array}$} & \multirow{2}{*}{$\begin{array}{c}\begin{array}{c}\text { High } \\
10 \text { percentile } \\
(4.11)\end{array} \\
0.159\end{array}$} \\
\hline \multirow{3}{*}{$\begin{array}{l}\text { LEGAL } \\
{[0,6.50]}\end{array}$} & $\begin{array}{l}\text { Low } \\
10 \text { percentile (1.19) }\end{array}$ & & & \\
\hline & $\begin{array}{l}\text { Mean } \\
(2.50) \\
\end{array}$ & -0.079 & -0.079 & -0.080 \\
\hline & $\begin{array}{c}\text { High } \\
10 \text { percentile (3.81) }\end{array}$ & -0.362 & -0.362 & -0.363 \\
\hline
\end{tabular}

\begin{tabular}{|c|c|c|c|c|}
\hline \multirow{2}{*}{\multicolumn{2}{|c|}{ Industrialized countries }} & \multicolumn{3}{|c|}{ KAOPEN [0, 4.39] } \\
\hline & & \multirow{2}{*}{$\begin{array}{c}\begin{array}{c}\text { Low } \\
10 \text { percentile } \\
(0.64)\end{array} \\
0.141\end{array}$} & \multirow{2}{*}{$\begin{array}{l}\text { Mean } \\
(2.99)\end{array}$} & \multirow{2}{*}{$\begin{array}{c}\begin{array}{c}\text { High } \\
10 \text { percentile } \\
(4.39)\end{array} \\
0.551\end{array}$} \\
\hline \multirow{3}{*}{$\begin{array}{l}\text { LEGAL } \\
{[0,6.50]}\end{array}$} & $\begin{array}{c}\text { Low } \\
10 \text { percentile (4.57) }\end{array}$ & & & \\
\hline & $\begin{array}{l}\text { Mean } \\
(5.75) \\
\end{array}$ & -0.144 & 0.112 & 0.265 \\
\hline & $\begin{array}{c}\text { High } \\
10 \text { percentile (6.47) }\end{array}$ & -0.320 & -0.064 & 0.089 \\
\hline
\end{tabular}

\begin{tabular}{|c|c|c|c|c|}
\hline \multirow{2}{*}{\multicolumn{2}{|c|}{ Less developed countries }} & \multicolumn{3}{|c|}{ KAOPEN $[0,4.39]$} \\
\hline & & \multirow{2}{*}{$\begin{array}{c}\text { Low } \\
10 \text { percentile } \\
(0.00)\end{array}$} & \multirow{2}{*}{$\begin{array}{l}\begin{array}{r}\text { Mean } \\
(1.51)\end{array} \\
0.786\end{array}$} & \multirow{2}{*}{$\begin{array}{c}\begin{array}{c}\text { High } \\
10 \text { percentile } \\
(4.39)\end{array} \\
0.398\end{array}$} \\
\hline \multirow{3}{*}{$\begin{array}{l}\text { LEGAL } \\
{[0,6.50]}\end{array}$} & $\begin{array}{c}\text { Low } \\
10 \text { percentile (1.19) }\end{array}$ & & & \\
\hline & $\begin{array}{l}\text { Mean } \\
\text { (2.50) }\end{array}$ & 0.726 & 0.522 & 0.133 \\
\hline & $\begin{array}{c}\text { High } \\
10 \text { percentile (3.81) }\end{array}$ & 0.463 & 0.259 & -0.130 \\
\hline
\end{tabular}

\begin{tabular}{|c|c|c|c|c|}
\hline \multirow{2}{*}{\multicolumn{2}{|c|}{ Emerging market countries }} & \multicolumn{3}{|c|}{ KAOPEN [0, 4.39] } \\
\hline & & \multirow{2}{*}{$\begin{array}{c}\begin{array}{c}\text { Low } \\
10 \text { percentile } \\
(0.00)\end{array} \\
1.222\end{array}$} & \multirow{2}{*}{$\begin{array}{c}\begin{array}{c}\text { Mean } \\
(1.42)\end{array} \\
1.113\end{array}$} & \multirow{2}{*}{$\begin{array}{c}\begin{array}{c}\text { High } \\
10 \text { percentile } \\
(4.11)\end{array} \\
0.906\end{array}$} \\
\hline \multirow{3}{*}{$\begin{array}{l}\text { LEGAL } \\
{[0,6.50]}\end{array}$} & $\begin{array}{c}\text { Low } \\
10 \text { percentile (1.19) }\end{array}$ & & & \\
\hline & $\begin{array}{l}\text { Mean } \\
(2.50)\end{array}$ & 0.609 & 0.500 & 0.293 \\
\hline & $\begin{array}{c}\text { High } \\
10 \text { percentile (3.81) }\end{array}$ & -0.116 & -0.226 & -0.433 \\
\hline
\end{tabular}


(continued)

\section{Investment}

\begin{tabular}{|c|c|c|c|c|}
\hline \multirow{2}{*}{\multicolumn{2}{|c|}{ Industrialized countries }} & \multicolumn{3}{|c|}{ KAOPEN [0, 4.39] } \\
\hline & & \multirow{2}{*}{$\begin{array}{c}\begin{array}{c}\text { Low } \\
10 \text { percentile } \\
(0.64)\end{array} \\
0.472\end{array}$} & \multirow{2}{*}{$\begin{array}{l}\text { Mean } \\
(2.99)\end{array}$} & \multirow{2}{*}{$\begin{array}{c}\begin{array}{c}\text { High } \\
10 \text { percentile } \\
(4.39)\end{array} \\
0.671\end{array}$} \\
\hline \multirow{3}{*}{$\begin{array}{l}\text { LEGAL } \\
{[0,6.50]}\end{array}$} & $\begin{array}{c}\text { Low } \\
10 \text { percentile (4.57) }\end{array}$ & & & \\
\hline & $\begin{array}{l}\text { Mean } \\
(5.75) \\
\end{array}$ & 0.237 & 0.362 & 0.436 \\
\hline & $\begin{array}{c}\text { High } \\
10 \text { percentile (6.47) }\end{array}$ & 0.093 & 0.217 & 0.292 \\
\hline
\end{tabular}

\begin{tabular}{|c|c|c|c|c|}
\hline \multirow{2}{*}{\multicolumn{2}{|c|}{ Less developed countries }} & \multicolumn{3}{|c|}{ KAOPEN $[0,4.39]$} \\
\hline & & \multirow{2}{*}{$\begin{array}{c}\text { Low } \\
10 \begin{array}{c}\text { percentile } \\
(0.00)\end{array} \\
1.448\end{array}$} & \multirow{2}{*}{$\begin{array}{c}\begin{array}{c}\text { Mean } \\
(1.51)\end{array} \\
1.089\end{array}$} & \multirow{2}{*}{$\begin{array}{c}\begin{array}{c}\text { High } \\
10 \text { percentile } \\
(4.39)\end{array} \\
0.406\end{array}$} \\
\hline \multirow{3}{*}{$\begin{array}{l}\text { LEGAL } \\
{[0,6.50]}\end{array}$} & $\begin{array}{c}\text { Low } \\
10 \text { percentile (1.19) }\end{array}$ & & & \\
\hline & $\begin{array}{l}\text { Mean } \\
(2.50)\end{array}$ & 1.136 & 0.777 & 0.095 \\
\hline & $\begin{array}{c}\text { High } \\
10 \text { percentile (3.81) }\end{array}$ & 0.826 & 0.467 & -0.215 \\
\hline
\end{tabular}

\begin{tabular}{|c|c|c|c|c|}
\hline \multirow{2}{*}{\multicolumn{2}{|c|}{ Emerging market countries }} & \multicolumn{3}{|c|}{ KAOPEN [0, 4.39] } \\
\hline & & \multirow{2}{*}{$\begin{array}{c}\text { Low } \\
10 \begin{array}{c}\text { percentile } \\
(0.00)\end{array} \\
1.257\end{array}$} & \multirow{2}{*}{$\begin{array}{l}\text { Mean } \\
(1.42)\end{array}$} & \multirow{2}{*}{$\begin{array}{c}\begin{array}{c}\text { High } \\
10 \text { percentile } \\
(4.11)\end{array} \\
1.117\end{array}$} \\
\hline \multirow{3}{*}{$\begin{array}{l}\text { LEGAL } \\
{[0,6.50]}\end{array}$} & $\begin{array}{c}\text { Low } \\
10 \text { percentile (1.19) }\end{array}$ & & & \\
\hline & $\begin{array}{l}\text { Mean } \\
(2.50)\end{array}$ & 0.850 & 0.802 & 0.710 \\
\hline & $\begin{array}{c}\text { High } \\
10 \text { percentile (3.81) }\end{array}$ & 0.368 & 0.320 & 0.228 \\
\hline
\end{tabular}


Table 5: Effect of Financial Development

on Current accounts, Saving, and Investment

A. Matrix for Emerging Asia

\begin{tabular}{c|c|c|c|c}
\hline \multicolumn{2}{c|}{} & \multicolumn{3}{|c}{ KAOPEN } \\
\cline { 2 - 5 } & $\begin{array}{c}\text { Low (closed) } \\
10 \text { percentile } \\
(0.00)\end{array}$ & $\begin{array}{c}\text { Mean } \\
(1.42)\end{array}$ & $\begin{array}{c}\text { High (open) } \\
10 \text { percentile } \\
(4.11)\end{array}$ \\
\hline \multirow{4}{*}{ LEGAL } & $\begin{array}{c}\text { Low } \\
10 \text { percentile } \\
(1.83)\end{array}$ & Bangladesh & & $\begin{array}{c}\text { Philippines, } \\
\text { Sri Lanka }\end{array}$ \\
\cline { 2 - 5 } & $\begin{array}{c}\text { Mean } \\
(3.05)\end{array}$ & India, China & $\begin{array}{c}\text { Korea, } \\
\text { Malaysia, } \\
\text { Thailand, } \\
\text { ex-China EA }\end{array}$ & Indonesia \\
\cline { 2 - 5 } & $\begin{array}{c}\text { High } \\
10 \text { percentile } \\
(4.49)\end{array}$ & & & $\begin{array}{c}\text { Hong Kong, } \\
\text { Singapore }\end{array}$ \\
\hline
\end{tabular}

B. Effects of a $10 \%$ change in Financial Development (PCGDP) on Saving and Investment, IDC and Emerging Asia

\begin{tabular}{c|cc}
\hline Country & Effect on Saving & Effect on Investment \\
\hline Japan & 0.347 & 0.504 \\
Germany & 0.249 & 0.423 \\
United Kingdom & 0.243 & 0.418 \\
\hline China & 0.513 & 0.797 \\
Hong Kong SAR & -0.552 & 0.154 \\
India & 0.578 & 0.840 \\
Indonesia & 1.238 & 1.319 \\
Korea & 0.186 & 0.597 \\
Malaysia & 0.116 & 0.551 \\
Philippines & 1.163 & 1.251 \\
Singapore & -0.882 & -0.065 \\
Thailand & 0.256 & 0.644 \\
Ex-China East Asia & 0.572 & 0.857 \\
\hline
\end{tabular}


Table 6: Effect of Equity Market Development on the Out-of-Sample Prediction Errors

\begin{tabular}{l|ccc}
\hline \multicolumn{4}{c}{ Dependent variable: Out-of-sample prediction errors } \\
\hline & $(1)$ & $(2)$ & $(3)$ \\
& SMTV & SMTO & SMKC \\
\hline \multirow{3}{*}{ Equity Market Development } & -0.0043 & -0.0020 & -0.0041 \\
West Hemisphere & {$[0.0014]^{* * *}$} & {$[0.0028]$} & {$[0.0019]^{* *}$} \\
& -0.0017 & -0.0116 & -0.0085 \\
Europe & {$[0.0075]$} & {$[0.0076]$} & {$[0.0075]$} \\
& -0.002 & -0.0052 & -0.0045 \\
Asia & {$[0.0069]$} & {$[0.0076]$} & {$[0.0074]$} \\
& 0.0166 & 0.0153 & 0.0151 \\
Africa & {$[0.0077]^{* *}$} & {$[0.0089]^{*}$} & {$[0.0079]^{*}$} \\
fix00 & 0.0007 & 0.0033 & 0.0152 \\
& {$[0.0089]$} & {$[0.0093]$} & {$[0.0110]$} \\
fix03 & 0.0061 & 0.0055 & 0.0051 \\
& {$[0.0051]$} & {$[0.0052]$} & {$[0.0047]$} \\
Constant & 0.0122 & 0.0096 & 0.0086 \\
& {$[0.0066]^{*}$} & {$[0.0083]$} & {$[0.0081]$} \\
\hline Observations & 0.0068 & 0.0059 & 0.0072 \\
Adjusted R-squared & {$[0.0064]$} & {$[0.0070]$} & {$[0.0069]$} \\
\hline * significant at 10\%; ** significant & 280 & 258 & 261 \\
\hline
\end{tabular}

NOTE: The regression is performed with the weights based on the ratio of GDP in current PPP. 
Figure 1: U.S. current account balance, 1970 - 2004

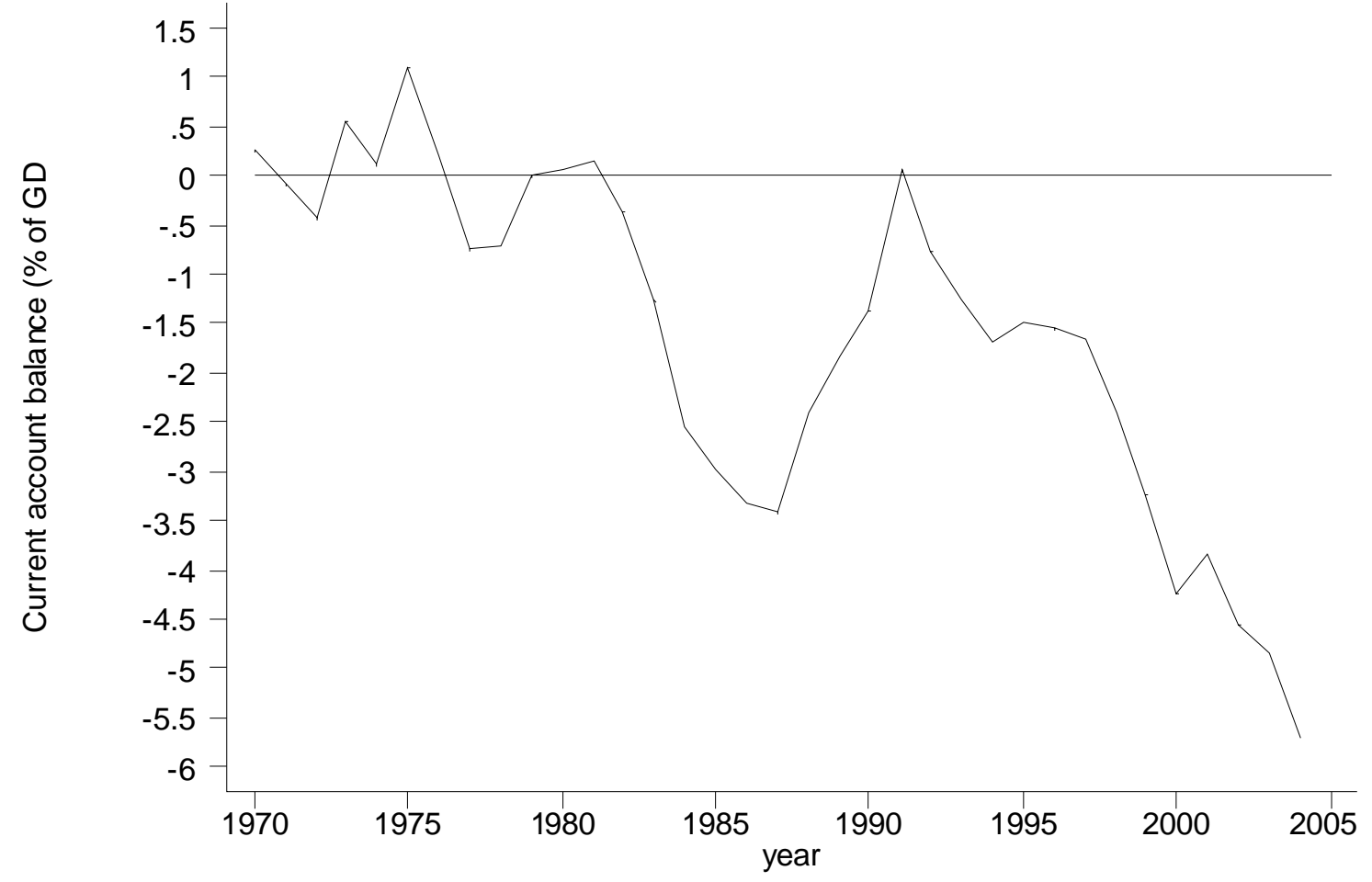


Figure 2: Implied current accounts
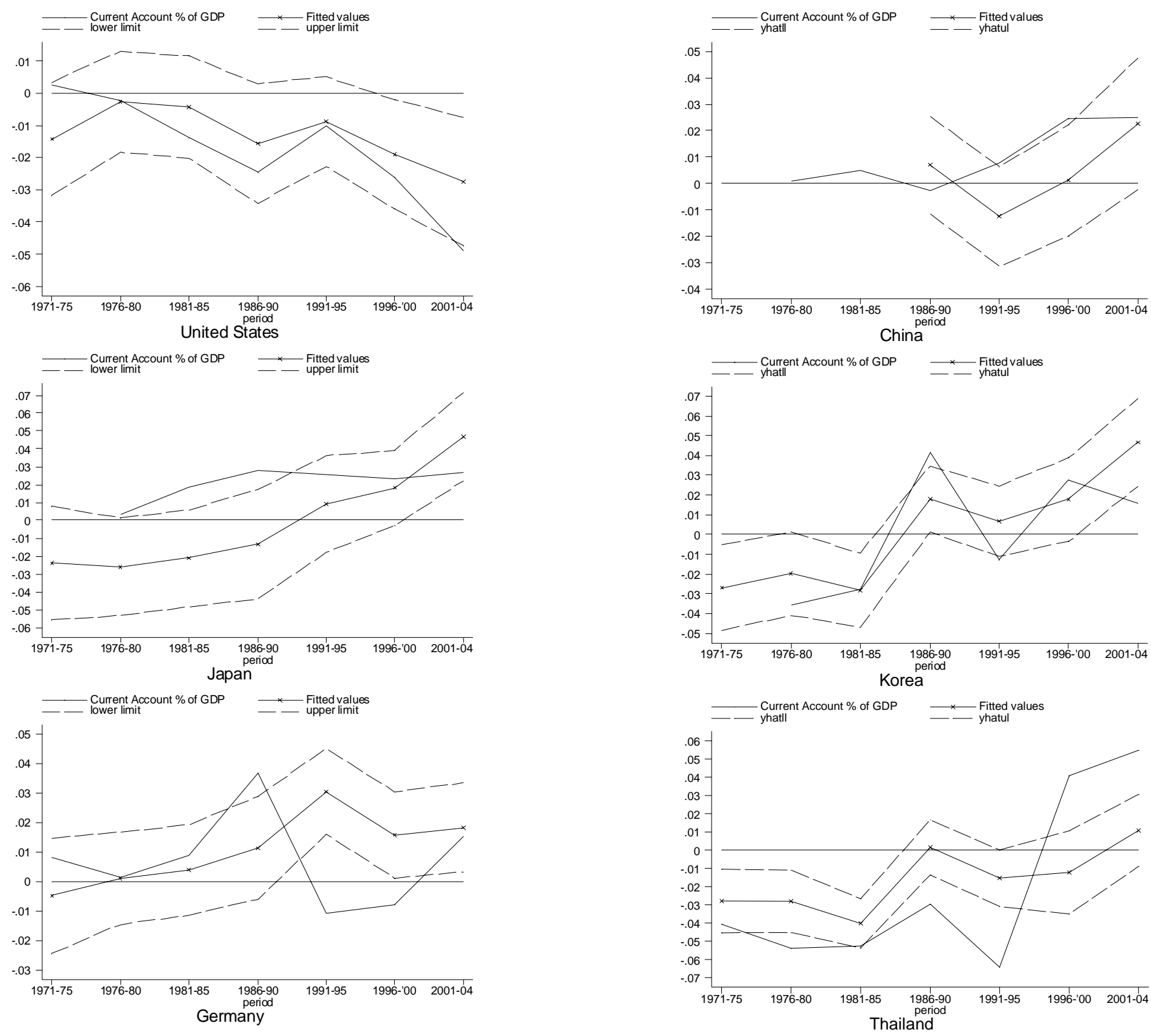
Figure 3-1: Out-of-sample predictions of current accounts with and without institutional variables, industrialized countries
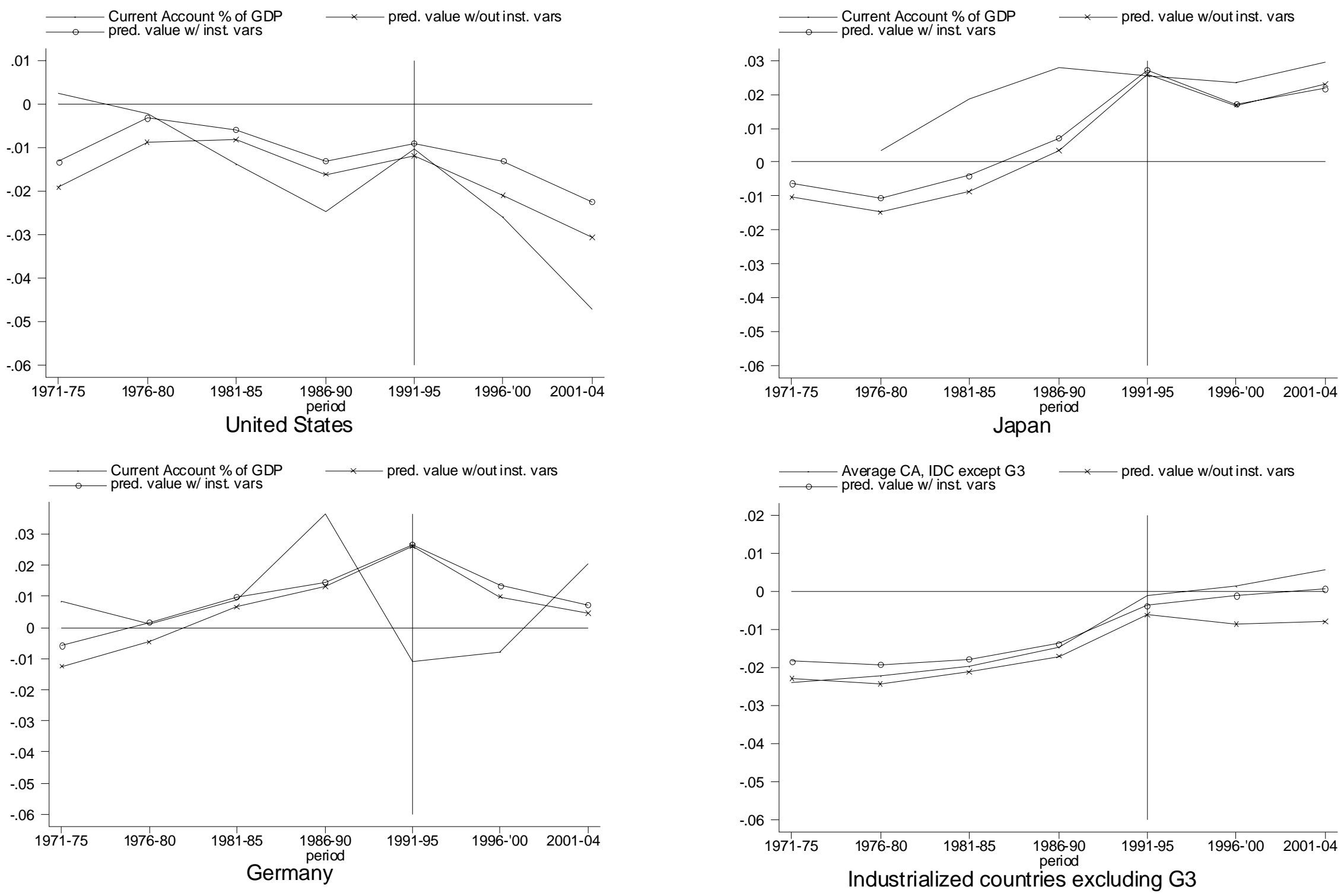
Figure 3-2: Out-of-sample predictions of current accounts with and without institutional variables, less developed countries
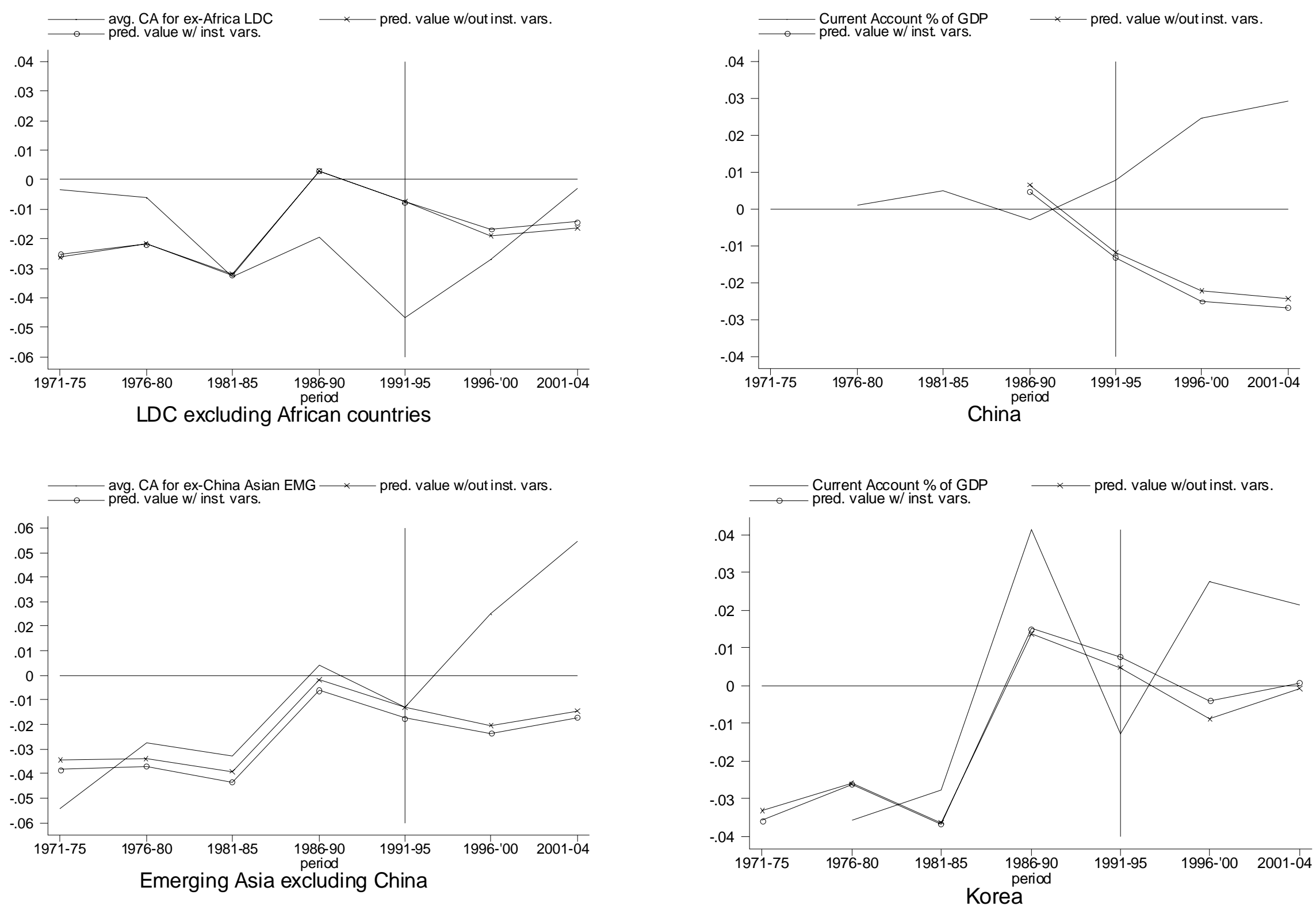
Figure 4: Out-of-sample predictions for U.S. national saving and investment
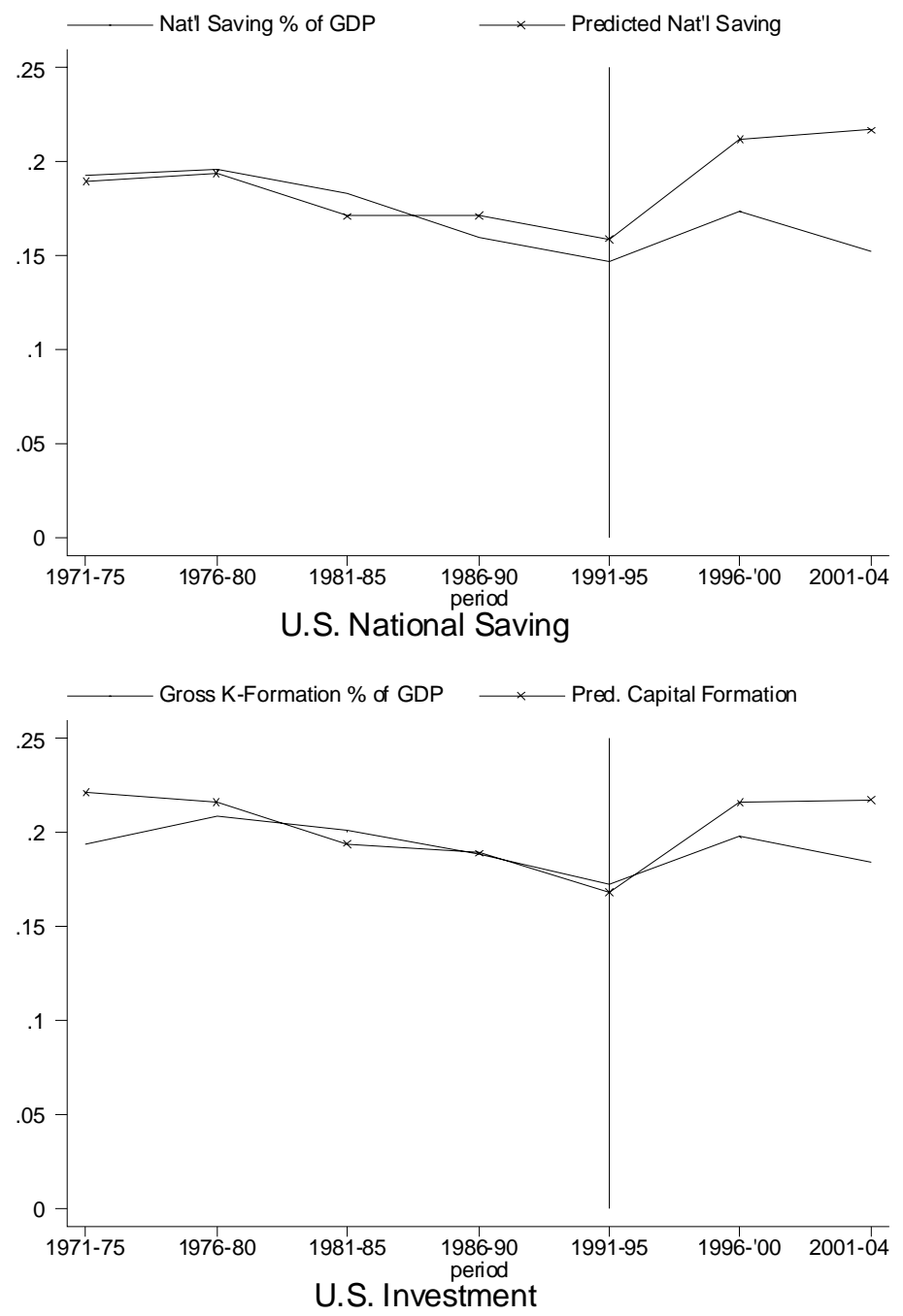

Figure 5: Out-of-sample predictions for Emerging Asia's national saving and investment (excluding China)

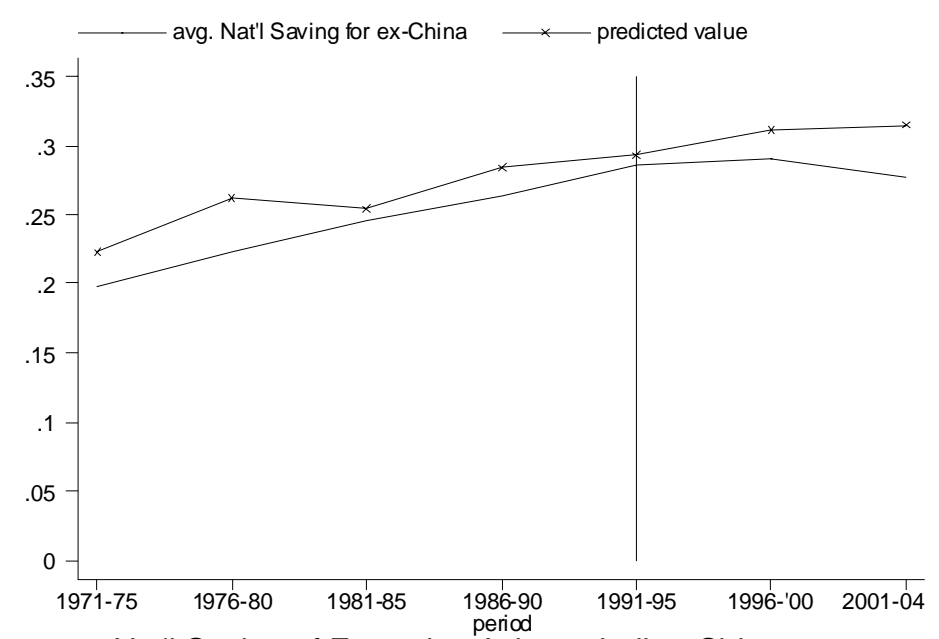
Nat'l Saving of Emerging Asia excluding China

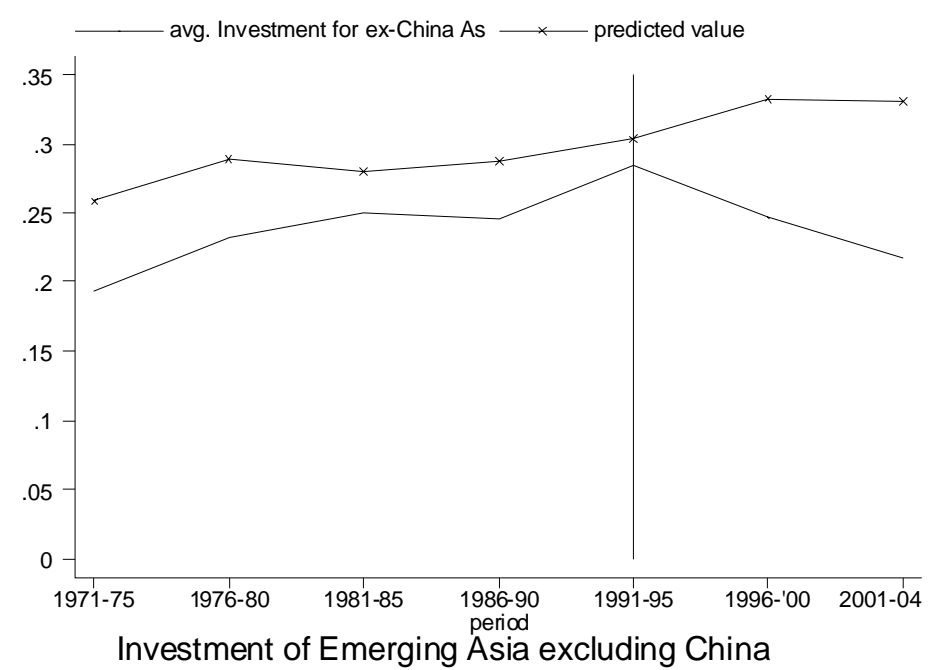


Figure 6: Equity Market Development in Various Measures (SMTV, SMTO, and SMKC)

(a) Industrialized Countries
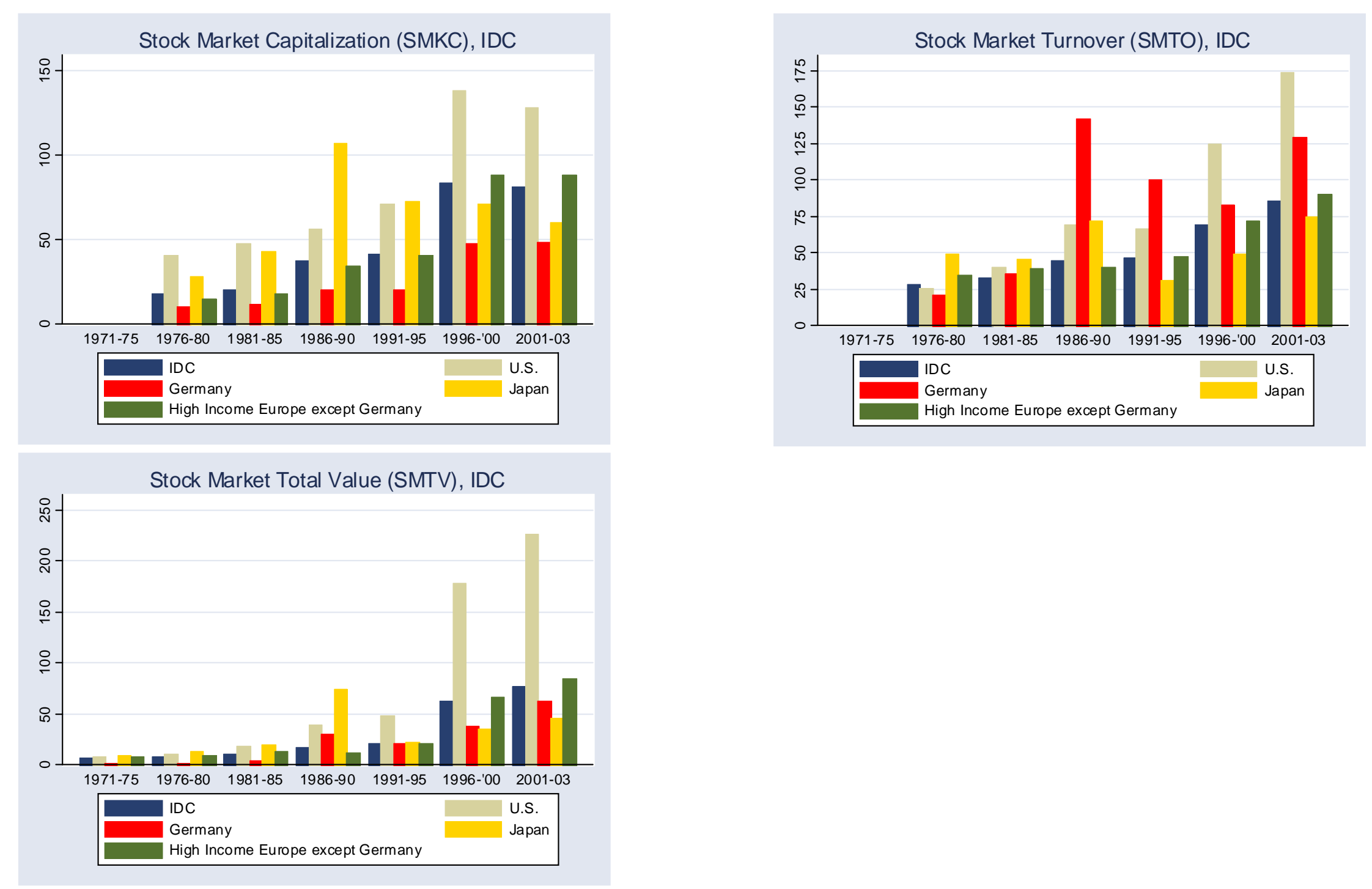
Figure 6: Equity Market Development in Various Measures (SMTV, SMTO, and SMKC)

\section{(b) Less Developed Countries}
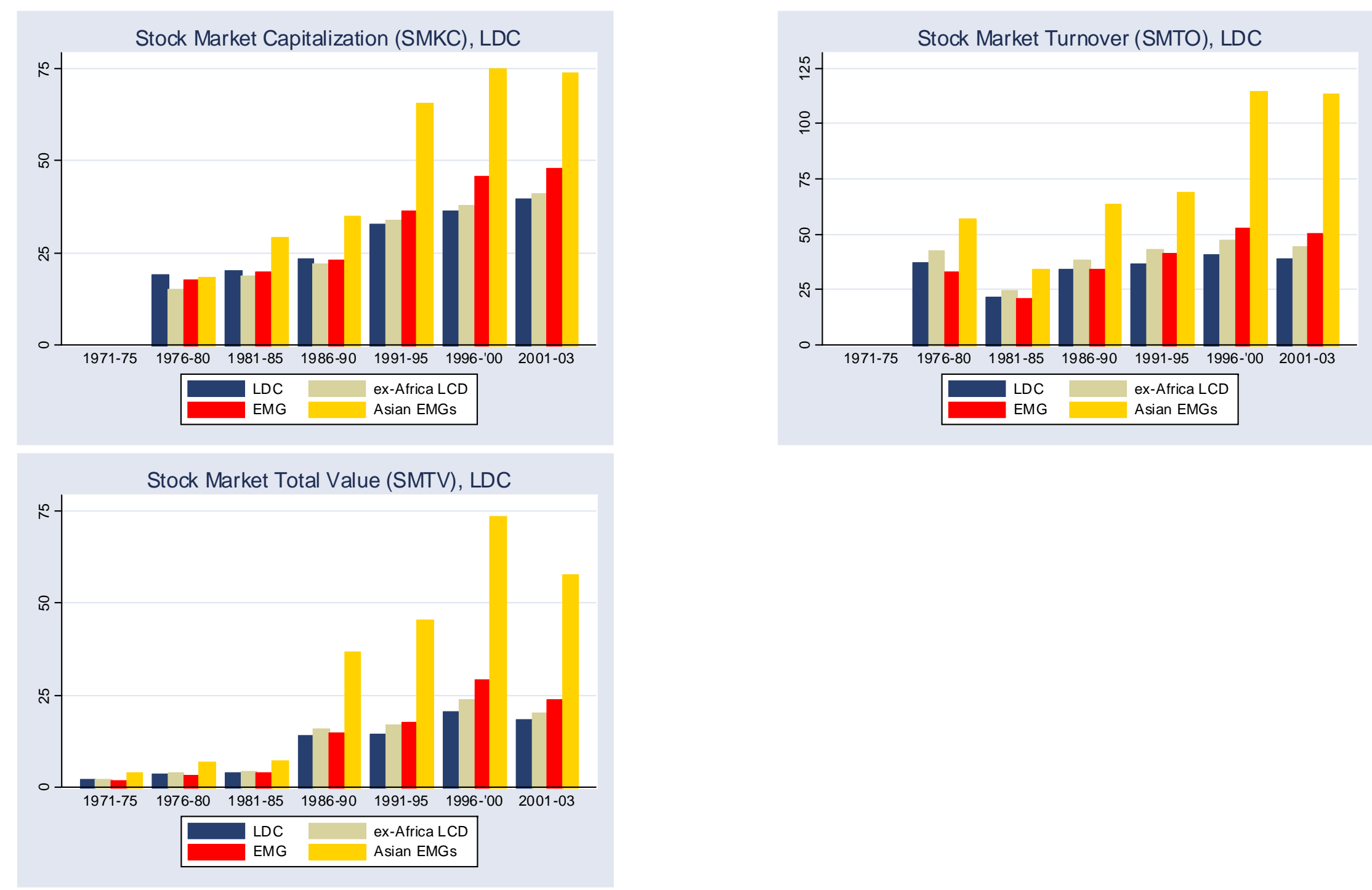
Figure 7: Out-of-Sample Prediction Errors and Equity Market Development

\section{Industrialized countries}
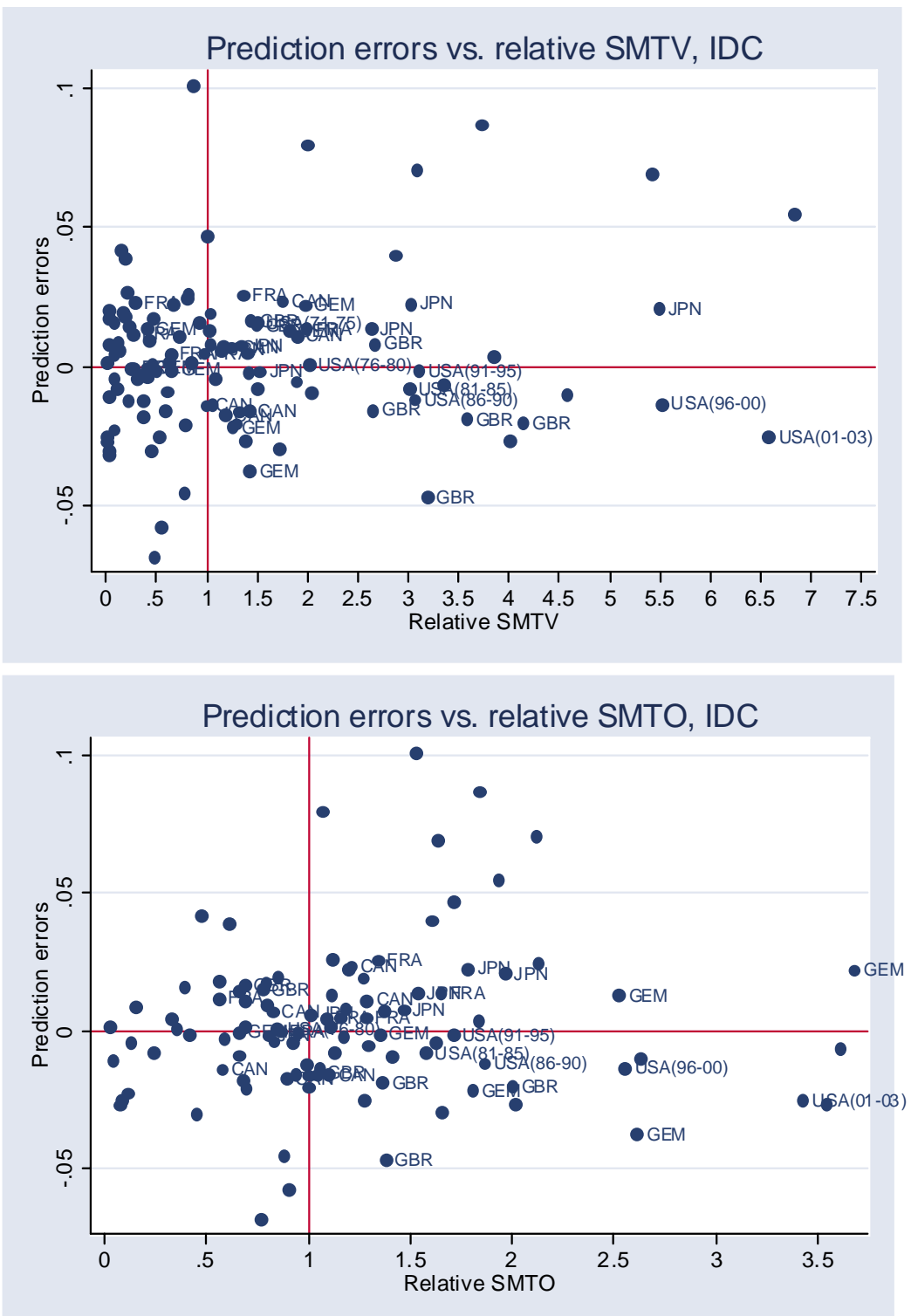

\section{Asian emerging market countries}
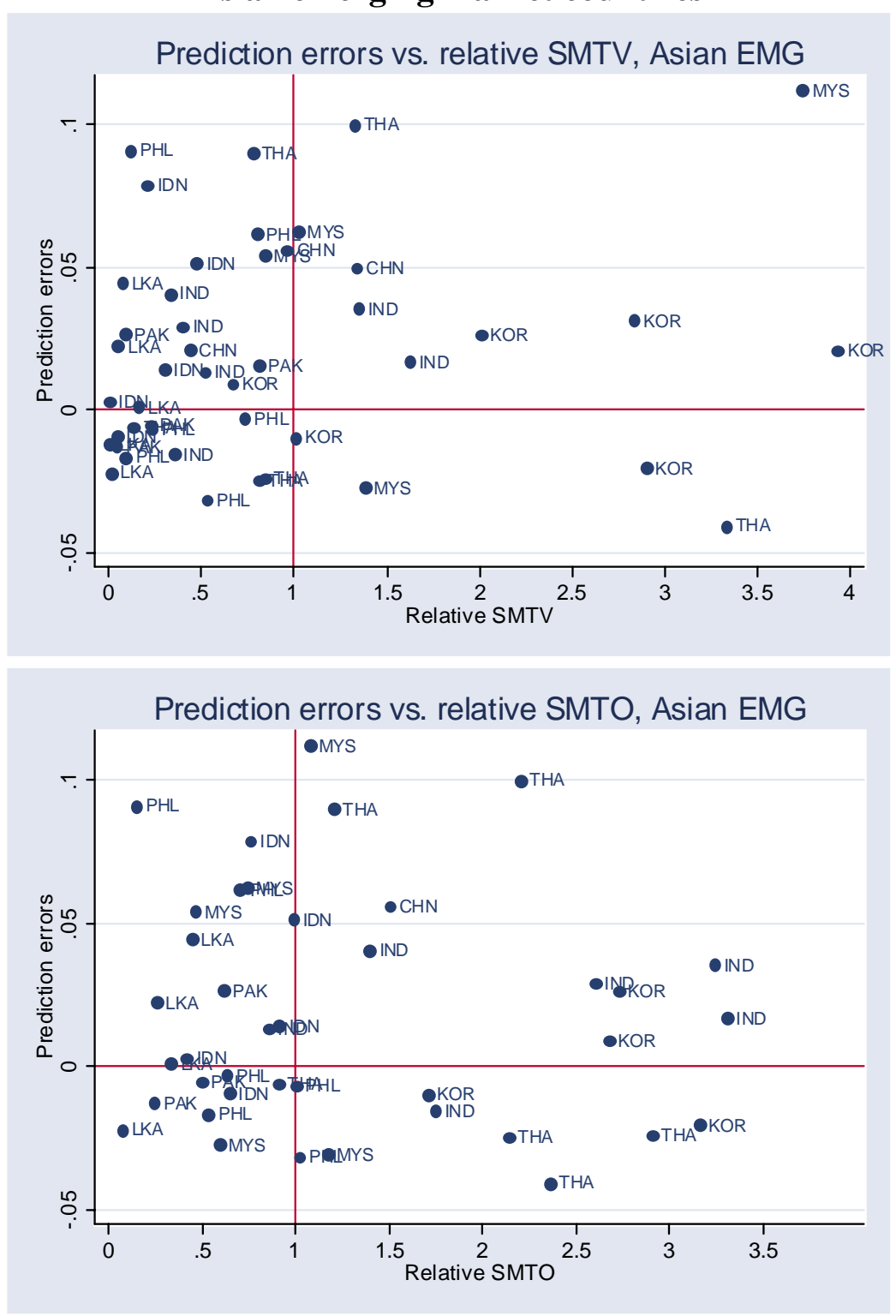
Figure 8: Prediction Errors and its Portion Explained by relative SMTV

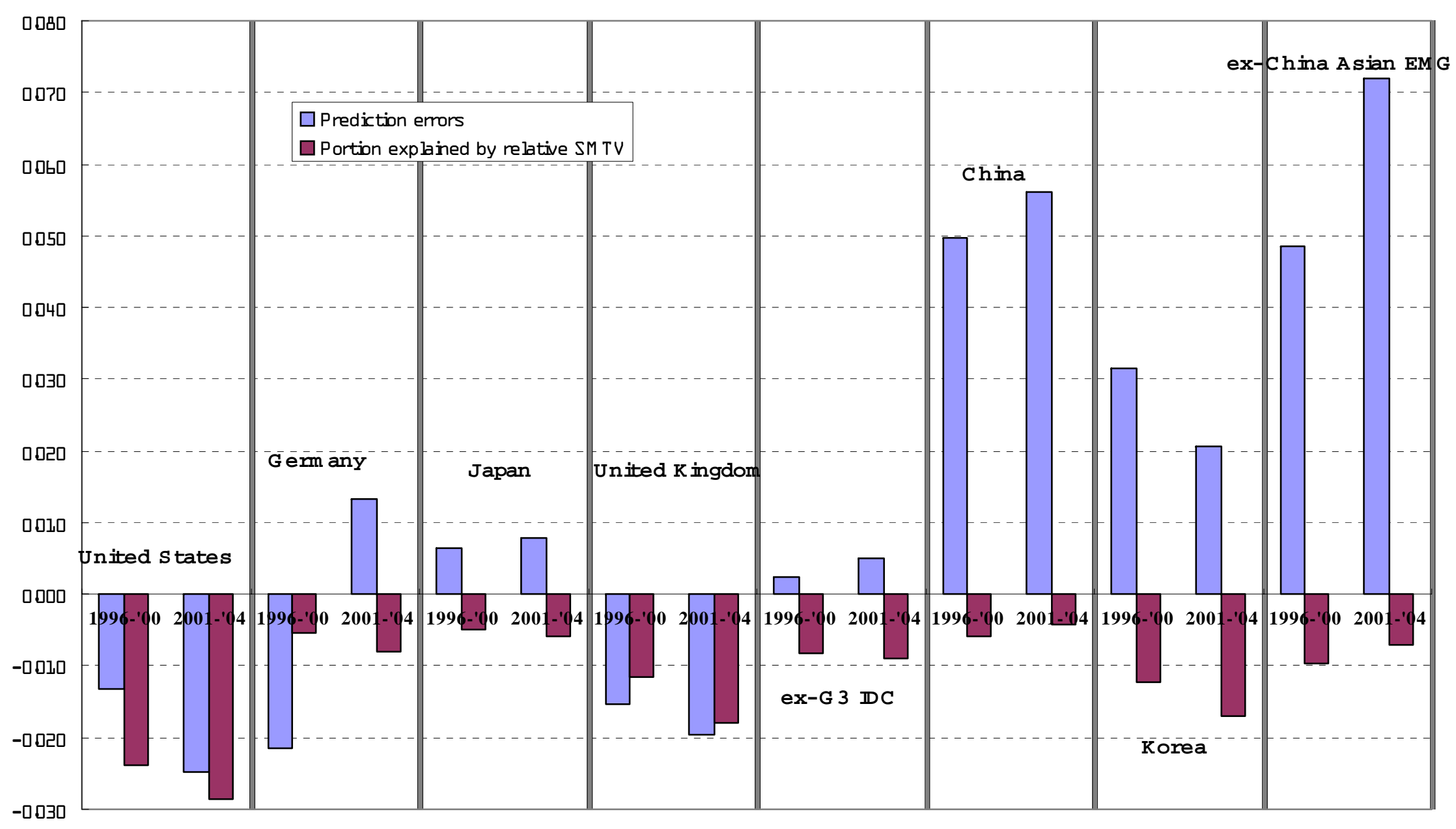

